\title{
THE COMPREHENSIVE PLANNING REQUIREMENT IN URBAN RENEWAL *
}

\author{
Danter R. Mandelikgr $\dagger$
}

Comprehensive ${ }^{1}$ plans are prepared and adopted to guide and coordinate community growth. To be effective, they must apply to public as well as private development, a relationship suggested in state planning enabling statutes, ${ }^{2}$ but left largely without sanction in state law. Real impetus to control public development through comprehensive planning has come from federal legislation, which has conditioned a wide variety of federal grants on the adoption of local or regional plans. Urban renewal was the first program to impose a federal comprehensive planning requirement. ${ }^{3}$ Through urban renewal, local public agencies acquire substandard areas, clear them and sell the cleared land for redevelopment, in accordance with a project plan for the cleared area. The federal legislation, in turn, requires a local

* Research for this article was sponsored by a grant from the Walter $E$. Meyer Research Institute of Law to the author and to Professor Roger Montgomery, Director, Urban Renewal Design Center, Washington University. The author wishes to acknowledge the help and assistance of Professor Montgomery in the research and writing of this article. Some of the information on which this article is based was obtained in interviews with local officials and other informants in St. Louis and Nashville. Since some of these sources have asked to remain anonymous, some statements of fact and opinion which appear in the text must stand unsupported by citation.

$\dagger$ Professor of Law, Washington University (St. Louis). B.A. 1947, LL.B. 1949, University of Wisconsin. J.S.D. 1956, Yale University. Member, Wisconsin
Bar.

1 Nomenclature in this field is not always consistent. Throughout this article, the words "comprehensive," "community," "master" and "general" plan are used interchangeably. In each instance, the reference is to a plan covering physical development and land use which is prepared on a community-wide basis. For discussion, see T. Kent, The Urban General Plan (1964).

2 See the derivative model in Advisory Comm. on City Planning and Zoning, U.S. Dep't of Commerce, A Standard City Planning Enabling Act $\S 9$ (1928).

3 Throughout this article, the terms "urban renewal," "slum clearance" and "redevelopment" are used interchangeably. The National Housing Act of 1949 was limited by its terms to slum clearance projects, in which slum areas are totally cleared and then redeveloped for new uses. Discussions which led up to the enactment of the federal statute centered on such projects and the two projects discussed in this article are slum clearance projects. President Eisenhower subsequentiy appointed an advisory committee on housing policies which, in 1953, recommended the extension of the slum clearance program to include neighborhood conservation and rehabilitation. President's Advisory Comm. on Gov's Housing Policies \& Programs, A Report to the President of the United Srates 115 (1953). The term "urban renewal" was coined for the new program, and, in 1954, the federal statute was amended to reflect these changes. See the definition of "urban renewal project" in 42 U.S.C. $\$ 1460$ (c) (Supp. I, 1966). 
legislative finding that the project plan "conforms to a general plan for the development of the locality as a whole." 4

Uncritical insistence in federal aid legislation on comprehensive planning has resulted in a proliferation of planning requirements since the adoption of the Federal urban renewal statute in 1949. Local, and sometimes regional, planning is now required by federal laws in programs as varied as highways, ${ }^{5}$ open space acquisition ${ }^{6}$ and the construction of rural water facilities. ${ }^{7}$ Extensive statutory insistence on comprehensive planning has not been accompanied, however, by an evaluation of the planning experience which has accumulated under existing federal aid legislation. A need for a relationship between comprehensive planning and public development has been assumed and a series of programs built around this relationship, but the value of the relationship has never been investigated.

Sufficient time has elapsed since the enactment of the federal urban renewal program to warrant appraisal of the nation's experience with urban renewal projects, especially early projects devoted to total slum clearance and redevelopment. ${ }^{8}$ These projects present an excellent opportunity to examine the contribution which comprehensive planning can make to the urban renewal process; this article will undertake such an evaluation. It will trace the evolution of the comprehensive planning requirement in urban renewal and its implementation in legislation and in federal administrative regulation. Planning and urban renewal experience will then be examined in two cities, St. Louis and Nashville, in which slum clearance ${ }^{9}$ projects are completed or are nearing completion.

442 U.S.C. $\$ 1455$ (a) (iii) (1964). A world-wide study found, in 58 per cent of the countries surveyed, a requirement that urban renewal proposals be "systematically" compared with comprehensive plans for the entire community. G. DuGGar, 1 Renewal of Town and Vitlage: A World-Wide Survey of Local Gov't ExpeRIENCE 82 (1965).

523 U.S.C. \& 134 (1964).

642 U.S.C. $\$ 1500$ (c) (Supp. I, 1966).

77 U.S.C. $\S \S 1926,1928$ (Supp. I, 1966). For a general survey see U.S. ADvisoRY Comm'n on Intergov'tal Relations, Impact of Federal URban Development Programs on Local Government Organization and Planning (1964).

8 While several recent studies of political leadership have focused on urban renewal problems, e.g., R. Dahl, Who Governs? Democracy and Power iN AN AMERICAN CiTY, ch. 10 (paperback ed. 1961), few have looked explicitly at city planning problems in an urban renewal context. One which does is $H$. Kaplan, Urban Renewal Politics: Slum Clearance in Newark (1963), dealing with a New Jersey community in which city planning was a late arrival and in which the planning function was thoroughly manipulated by an aggressive urban renewal authority. Id. at 114-34. Hearings on urban renewal in the District of Columbia also revealed some distortion of the city planning process in order to justify specific urban renewal projects. H.R. ReP. No. 1947, 88th Cong., 2d Sess. 11, 12, 43-47 (1964). No evidence of clearcut manipulation was discovered in either St. Louis or Nashville.

$\theta$ Both the Nashville and St. Louis projects are slum clearance efforts in which a public agency acquires a slum area, clears it and then disposes of the cleared land 
I. The Origins and Role of the Planning Reguirement: The Framework FOR URBAN RenewaL

An inquiry into the role of planning in urban renewal begins with the primitive state of the planning art at the time the urban renewal concept was first articulated in the late 1920's and early 1930's. ${ }^{10}$ Planners worked in simplified physical dimensions; they concentrated on optimum end-states and worked toward a static model of the physical community. ${ }^{11}$ Nor was their work well supported, either politically or financially, and during the Great Depression the planning function was severely curtailed at the local level. ${ }^{12}$ Weaknesses in the planning machinery were admitted by those who most strongly supported a comprehensive planning basis for urban renewal; ${ }^{\mathbf{1 3}}$ the inclusion of a comprehensive planning requirement in that program was intended to strengthen the planning process generally. ${ }^{14}$

for private redevelopment according to a redevelopment plan. Costs of acquisition, clearance and preparation for redevelopment usually exceed the amount realized upon resale. Two-thirds of the difference is provided by a federal subsidy and one-third by a local matching contribution. The local contribution may be in cash or in noncash contributions such as schools and other public improvements.

10 An excellent analysis of the origins and shortcomings of the early planning movement in America is contained in N. Johnston, Harland Bartholomew: His Comprehensive Plans and Science of Planning 188-89, 1964 (unpublished dissertation in University of Pennsylvania Fine Arts Library). However, there is surprisingly little literature analyzing the ideological basis of the planners' conclusions. An excellent recent study, well-grounded in careful empirical research is A. ALTSH ULER, The City Planning Process: A Political Analysis (1965). Altshuler states:

The expert's job, strictly speaking, is to measure the effects of action possi-

bilities on variables. His technical conclusions can do no more than provide

the factual basis for nontechnical judgments of the significance of alternatives

for values. The variables of which operational objectives are composed are

related to values, however, and when consensus is sought they often provide

the clearest indicators of the values themselves.

Id. at 338. Another provocative writer has developed the concept of the value "screen," which is applied by planners when they select from a range of alternatives. P. Clavel, A Planning Decision for Extensive Redevelopment in Binghamton (undated) (unpublished manuscript on file in Washington University Law Library). See also M. Myerson \& E. Banfield, Politics, Planning, and the Public INTEREST (1955), which examines the impact of the planning process on the selection of public housing sites in Chicago.

11 See Kaplan, Comments on the Demonstration Cities Program, 32 J. Am. Inst. PlanNers 366, 370 (1966): "Acceptance by the planner of a somewhat organismic concept of the city, one in which only middle class values were acceptable, impeded a real understanding of the city." See also Alonso, Cities and City Planners, 92 DaEDalus 824 (1963).

12 See Johnston, supra note 10 , at $188-89$.

13 This point is made forcefully in Augur, City Planting and Honsing-May They Meet Again, in Am. Soc'y of Planning Officials, National Conference on Planning (1940). See also Am. Soc'y of Planning Officials, Planning 1943, at 95-96; Report of the Comm. on Urban Redevelopment, in AM. Soc'y oF Planning Officials, National Conference on Planning 173 (1942).

14 See, e.g., Bigger, The Place of Honsing in Urban Reconstruction, in AM. Soc'y of Planning Offictals, National Conference on Planning 146 (1941). Many of those connected with the development of the urban renewal idea viewed the new program as requiring an extensive reworking of the city planning framework. This perception, although valid, was not reflected in the urban renewal legislation as it was enacted at the federal and state levels. 
From discussions at professional meetings and national conferences emerged the view that planning would contribute a comprehensive outlook, which would provide a meaningful context for the urban renewal effort. What more specific benefits were to be contributed by planning were not precisely indicated, but three points may be isolated at which a comprehensive planning perspective can become important. First, planning can have geographic significance, by defining the area in which urban renewal is supposed to operate. Second, it can help define the goals which the urban renewal program is intended to implement. Finally, planning can provide a check on urban renewal decision-making, by offering an external review process through which the conduct of the program can be evaluated.

Problems concerning the geographic scope of urban renewal planning can be covered quickly. Although other federal statutes have increasingly required a metropolitan planning perspective on local projects which receive federal financial assistance, ${ }^{15}$ planning in urban renewal is limited to the municipality in which the program is to be conducted. This emphasis is unfortunate. It inhibits any program which is directed even in part to the improvement of the housing supply, since housing demands and housing needs are regional in nature. ${ }^{16}$ These difficulties were foreseen by the urban renewal pioneers; they insisted that planning for urban renewal (and indeed for all purposes) be conducted on a metropolitan scale, ${ }^{17}$ and there even have been suggestions that the urban renewal agency should secure suburban rehousing sites in conjunction with slum clearance. ${ }^{18}$ Nevertheless, although early federal legislative proposals had included a metropolitan planning requirement, ${ }^{10}$ it was dropped from the law as finally enacted. ${ }^{20}$ The remaining problems-assessment

15 See especially the provisions of Title II of the Demonstration Cities and Metropolitan Dev. Act of 1966. 80 Stat. 1261 (1966).

16 See W. Grigsby, Housing Markets and Public Policy 287 n.34 (1963).

17 E.g., National Conference on Planning (1942) supra note 13, at 173. The early Thomas bill contemplated that slum clearance projects would be planned and executed with entire metropolitan areas in mind. S. 953, 78th Cong., Ist Sess. $\S \S 10,18(3)$ (1943).

18 Greer, City Planning and Urban Redevelopment 8 (Policy Comm. Memorandum of Division of Defense Housing Coordination, Office for Emergency Management, Executive Office of the President, June 25, 1941). Greer worked closely with the economist, Alvin Hansen, who along with Alfred Bettman was the principal draftsman of the Thomas bill. Interview with Coleman Woodbury, former Assistant Administrator (Program), National Housing Agency during the period 1942-46, in St. Louis, Mo. [hereinafter cited as Woodbury Interview]; Hearings on Post-War Economic Policy and Planning, Before the Subcomm. on Housing and Urban Redevelopment of the Special [Senate] Comm. on Post-War Economic Policy and Planning, 79th Cong., 1st Sess. 1605 (1945) [hereinafter cited as Post-War Hearings].

19 See note 17 supra.

20 While the federal statute requires the federal agency to encourage the operation of metropolitan urban renewal agencies, 42 U.S.C. $\$ 1451$ (b) (1964), this provision has never been effectively implemented. 
of comprehensive planning's impact on the goals of the renewal program and on the processes through which urban renewal projects are formulated and carried out-can best be considered in the context of the two principal decisions which urban renewal requires, project selection and planning for redevelopment.

\section{Project Selection}

At the heart of urban renewal, and forming the essential legal element in the design of urban renewal legislation, is the project concept-a reasonably compact and contiguous area which is to be reshaped by the redevelopment process. Architects and planners explored new methods of reconstructing blighted residential neighborhoods in New York ${ }^{21}$ and other cities ${ }^{22}$ during the 1930's, and the project concept reflects the attachment which these professionals acquired for the neighborhood unit as the physical model for replanning and rebuilding.

Structuring urban renewal in project form creates the legally significant physical setting in which urban renewal must be carried out. Legally important criteria center on two stages in the renewal process, the qualification and selection of project areas and their redevelopment ${ }^{23}$ following clearance. At the redevelopment stage, the character of the project is shaped by the project plan, known either as the "urban renewal" or "redevelopment" plan. Land in the project is to be sold at its "fair value for uses" 24 specified in the project plan, which must in turn conform to the general plan for the community.

The need to relate individual projects to the community plan was frequently asserted, ${ }^{25}$ and the early proponents of urban renewal

21 See, e.g., the periodical issued for a short time by the Land Utilization Committee of the New York Building Congress entitled LAND USAGE, HousING \& CITY Planning June-July 1936, at 4; Id. Nov.-Dec. 1936, at 5. See also N.Y. Bldg. Congress, Inc., Problems Affecting Housing: A Summary of Points of View (March, 1938); Veiller, Honsing, in REPORT OF THE [N.Y.] CITY CoMm. ON PLAN \& Survex 42-51 (1928). Perry's contributions to the neighborhood unit concept are also significant. E.g., C. Perry, The Rebuizdng of Blighted Areas: A Study of the Neighborhood Unit in Replanning and Plot Assemblage (1933); Perty, The Neighborhood Unit, 7 Regronal SuRvey of NEW YORK aNd ITS ENVTrons 106-13 (1929).

22 For early discussions, see, e.g., Mitchell, Prospects for Neighborhood Rehabilitation, in Natronal Ass'N of Housing OfFictals, Houstng Yearbook, 1938, at 134 (C. Woodbury ed.) ; Rehabilitation of the Blighted District: $A$ Cooperative Enterprise, in Am. Soc'y of PlanNing Officials, Planning for the Future of AMrerican Cities 73 (1935).

23 For an early recognition of the relation of these problems to site selection in public housing, see Augur, supra note 13, at 157.

2442 U.S.C. $\$ 1460$ (c) (4) (1964).

25 See, e.g., Bettman, City and Regional Planning in Depression and Recovery, in Nat'l Conference on City Planning, Planning and National Recovery 
apparently intended that the planning objectives implicit in redevelopment should also dictate project selection. ${ }^{26}$ Despite one attempt to include such a provision, ${ }^{27}$ however, the federal statute has never based project qualification on the satisfaction of community planning objectives. Slum clearance projects qualify for federal aid (and are authorized by state law) on the basis of what they remove from a city, and a project must qualify as a slum or blighted area before it can receive federal assistance or be acquired under state statutes. ${ }^{28}$

This emphasis is fundamental. It affects and clouds the role of planning in project selection, for the qualification of areas on the basis of external physical conditions hides problems of choice in a program in which rival projects compete for attention and not all qualifying areas can be included immediately. Conceivably, these issues present planning questions, but they were barely considered in discussions of the role of planning in slum clearance. ${ }^{29}$ Instead,

11-12 (1933); Buttenheim, Where City Planning and Housing Meet, in NaT'L CoNference on City Planning, Planning Problems of Town, City and Regron 114 (1929); Wright, City Planning in Relation to the Housing Problem, in NaT'L Conference on City Planning, Planning Problems of Town, City and Region 17 (1932).

26 See Bettman, supra note 25; Bettman, Federal and State Urban Redevelopment Bills, in Am. Planning \& Civic Ass'n, American Planning and Civic Annual 166, 168 (1943); Bettman, Housing Projects and City Planning, 1 Law \& Contemp. Prob. 206, 209 (1934); Grant, A Planning Pattern for Urban Redevelopment, in Am. Planning and Civic Ass'n, American Planning and Civic ANNUAL 202, 203 (1945); Report of the Comm. on Urban Redevelopment, in Am. Soc'y of Planning Officlals, Planning 1943, at 93, 100; Report of the Comm. on Urban Redevelopment, in AM. SoC'y of Planning OfFicials, National. ConfERence on Planning 166, 175 (1942). This view is further developed in

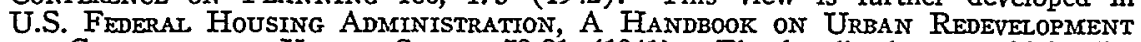
FOR CITIES IN THE UNITED STATES 78-81 (1941). The handbook was widely distributed. Woodbury Interview. Professor Woodbury provided helpful background information on the development of federal and state urban renewal legislation.

27 The 1954 bill amending the slum clearance title of the National Fousing Act, as originally introduced and passed in the House of Representatives, redefined an urban renewal project to mean: activities in an urban renewal area for the elimination and prevention of slums and blight "in accordance with an urban renewal plan to achieve sound community objectives for the establishment and preservation of well-planned residential neighborhoods of decent homes and suitable living environment for adequate family life." H.R. 7839, 83d Cong., 2d Sess. \$411 (1954). This provision was eliminated by the Senate committee, which felt "that such general criteria were too vague and could be construed in such a way as to permit a major change in the basic objective of the existing law." S. REP. No. 1472, 83d Cong., $2 d$ Sess. 38 (1954). The Senate version was retained in conference. CoNF. REP. No. 2271, 83 d Cong., 2 d Sess. 79, 80 (1954).

28 The federal statute refers to the acquisition of "a slum area or a deteriorated or deteriorating area" but does not provide a further definition. 42 U.S.C. $\$ 1460$ (c) (1) (i) (Supp. I, 1966). State slum clearance laws turn on the acquisition of slum, blighted and deteriorated areas, which are usually defined. See Draft Bill Prepared by the Office of General Counsel, Department of Housing and Urban Development for the Assistance of Local Counsel and Officials in Drafting State Urban Renewal Legislation, or Amendments of Existing State Urban Renewal Laws, $\S \S 19$ (h), 19(i) (Nov. 15, 1965).

29 Note, however, the early comments of Catherine Bauer Wurster on the inability of planning commissions to make adequate judgments in the selection of 
projects qualify under rating techniques which were not available in published form until $1946,{ }^{30}$ and which had not been developed with the needs of the slum clearance program in mind. ${ }^{31}$ Administratively acceptable blight levels qualify large areas in most cities, ${ }^{32}$ simplifying the task of project qualification. Judicial reluctance to upset local project qualifications further isolates the blight determination process from inspection..$^{33}$

Other planning issues potentially latent in project selection are tied to the housing objectives that were incorporated in the federal slum clearance legislation. Initially, slum clearance projects were limited to residential slums, unless nonresidential blighted areas were cleared for residential redevelopment. ${ }^{34}$ Opportunities for nonresidential clearance have since been enhanced by federal amendments which permit the nonresidential redevelopment of nonresidential slums if there

sites for public housing: "The failure in many instances to present other than a purely theoretical analysis has led to innumerable difficulties." AM. Soc'y of Planning Officials, National Conference on Planning 166 (1940). For early, tentative examinations of criteria for site selection, see C. WoODBURY \& F. Gutheim, Rethinking Urban Redevelopment 18 (Public Administration Serv., Urban Redevelopment Series No. 1, 1949) ; Criteria for Selection of Initial Redevelopment Areas, in Am. Soc'y of Planning Offictals, Planning 1948, at 43. The 1948 report, which was prepared by a committee headed by the then Director of Planning for the Chicago Housing Authority, contains some ideas which are both inconsistent and naive. Thus, areas selected should "not add to an existing oversupply of vacant land for any specific use." Id. at 44. Is "oversupply" to be determined by the "market" or by the exercise of an independent "planning" judgment? Is there an "oversupply" of housing for Negroes if there is a high vacancy rate in the overcrowded Negro ghetto? For a critique of this report, see id. at 49. The failure to develop a literature on the problems of site selection is surprising, to say the least.

30 Amertcan Public fiealte Ass'n, An Appraisal for Measuring the Quality of Housing (1946).

31 The work on the American Public Health Association (APHA) housing survey, supra note 30 , had been done before the federal slum clearance program was enacted and was primarily intended for use by housing and health inspectors. Interview with William C. Loring, Urban Sociologist, Division of Environmental Eng'r and Food Protection, U.S. Public Health Serv., in Washington, D.C., January 12, 1965. Dr. Loring was associated with the study group that carried out the basic research for the APHA survey method.

32 For example, all "old law" tenement buildings in New York City are qualified for federal assistance under the slum clearance program, without additional structural surveys. Slayton, Impact of the Community Renewal Program on Urban Renezval, in Am. Inst. of Planners, A Report of the Newark Proceedings 151,153 (1964). Slayton was formerly commissioner of what was then the Urban Renewal Administration of the Federal Housing and Home Finance Agency. Old law tenements are apartment buildings erected before the adoption of the New York tenement house act of 1901.

33 On project boundaries, see Berman v. Parker, 348 U.S. 26, 35 (1954) ; Ellis v. City of Grand Rapids, 257 F. Supp. 564 (W.D. Mich. 1966). No case has been found which considered questions of priorities in project selection.

34 Housing Act of 1949, $\S 110(\mathrm{c})(1), 63$ Stat. 420 (1949). In addition, "blighted" open land projects had to be redeveloped for predominantly residential uses. Id. 
is a local determination that nonresidential redevelopment "is necessary for the proper development of the community." 35

The introduction of housing objectives in the slum clearance legislation requires consideration of the impact of project selection on housing policy, at least as a strategy if not as a planning problem. One economist, ${ }^{36}$ who has considered the impact of urban renewal on housing, has suggested that clearance and demolition should always follow the abandonment of slum areas by the private market, because the filtering process works best when abandoned units at the bottom of the fitness scale are removed by public action. Selection of relatively depopulated areas will also reduce the dislocation of population which may contribute to the creation of slums elsewhere. Strategy problems of this kind were simply not considered by advocates of the planning process in urban renewal, who were largely unsympathetic to the use of slum clearance to advance housing goals. ${ }^{37}$ Significantly, an early federal bill authorizing federal aid for urban renewal did not contain a residential limitation on the character of slum clearance projects. ${ }^{38}$ That the imposition of a residential limitation would be viewed as hostile to the implementation of planning objectives can be explained historically. The public housing program had been initiated during the New Deal, and planners wanted slum clearance to be more than an extension of the public housing effort. ${ }^{39}$

3542 U.S.C. $\$ 1460$ (c) (Supp. I, 1966). The wording is less than clear. There is possibly implicit in this language a requirement that the decision to select a nonresidential project be tied to a plan for the community or, at least, to a statement of community objectives. Compare the language authorizing loans and advances to acquire "open land" projects for nonresidential development: "[I]f the governing body of the local public [renewal] agency determines that such redevelopment for predominantly nonresidential uses is necessary and appropriate to facilitate the proper growth and development of the community in accordance with sound planning standards and local community objectives. - ." 42 U.S.C. $\$ 1460$ (c) (1964).

36 GrigsBy, supra note 16 , at 286 . This is the only systematic analysis of the implications of alternative urban renewal strategies, written from the point of view of an economist.

37 Although the original limitation to housing clearance or housing reuse is not necessarily antagonistic to comprehensive planning, some of the early proponents of urban renewal viewed an emphasis on housing as restricting the full implementation of the community plan. Statements of this kind appeared frequently. See, e.g., Bettman, Urban Redevelopment Legislation, in CITY AND REGIONAL PAPERS 111, 114 (A. Comey ed. 1946) ; Blucher, The Share of the Planer and the Lawyer, in Rehabilitation of the Blighted District: $A$ Cooperative Enterprise, supra note 22, at 74; Report of the Comm. on Urban Redevelopment, in An. Soc'y of PianNING Offictals, National Confereince on Planning 250, 256 (1941).

38 See S. 953, 78th Cong., 1st Sess. $\$ \$ 10,18(8), 18(16)$ (1943), introduced by Senator Thomas of Utah. Alfred Bettman, one of the leading proponents of the planning idea in urban renewal, assisted substantially in the drafting of this legislation. See text accompanying notes 47-48 infra; Post-War Hearings 1610 (testimony of A. Bettman). A residential limitation was also omitted from an early bill introduced by Senator Robert Wagner. S. 1163, 78th Cong., 1st Sess. $\$ 3$ (a)(1) (1943).

39 This explanation is to be inferred strongly from reports and discussions of urban redevelopment in the period between the two world wars, and was reinforced by Coleman Woodbury. Woodbury Interview. 
The impact of urban renewal on racial patterns in the housing supply, so important in cities like St. Louis and Nashville, was likewise ignored. For example, a comprehensive plan might assist in the setting of project priorities by deciding which neighborhoods have the social and ethnic characteristics to best withstand displacement. ${ }^{40}$ But the early concentration of city planning and housing reform on physical concerns prevented an orientation which might have given prominence to nonphysical issues, in spite of occasional lip service to social and economic problems. ${ }^{41}$ Although urban renewal would displace racial and other minorities, urban renewal proponents opposed ${ }^{42}$ the relocation requirement, ${ }^{43}$ finally added to the federal law, that displaced site residents be afforded decent housing. This requirement was added at the insistence of spokesmen for the housing movement.

\section{Planning for Redevelopment}

While planning has not had much influence on project selection, ${ }^{44}$ planning was intended to play a critical role in shaping project redevelopment. Federal legislation requires that the urban renewal project

40 Studies of this kind are presently being carried out under the federally-aided Community Renewal Program, which attempts to determine urban renewal priorities on a community-wide basis. For one particularly imaginative approach, see PuerTo Rico Urban Renewal \& Housing Administration, San Juan Metropolttan Area Community Renewal Program (undated).

41 E.g., Planning 1943, supra note 13, at 100 . The lack of attention to economic and social issues in city planning was well recognized. Greer, supra note 18 , at 4; G. Greer \& A. HaNSEN, URban RedevelopMent and Housing 8 (Nati Planning Ass'n, Planning Pamphlet No. 10, Dec., 1941). The Thomas bill would have authorized the federal redevelopment agency "to institute research into the economic and social factors of the physical development of urban communities." S. 953, 78th Cong., 1st Sess. $\$ 7$ (1943). The federal agency has only recently issued guidelines on economic studies in city planning. U.S. DEPT. OF HousING AND URban Dev., Economic Factors IN Urban Planning Studies (Urban Renewal Serv., Technical Guide No. 20, Feb. 1966).

42 Letter from Alfred Bettman to Catherine Bater (Mrs. William Wurster), May 18, 1943, at 4, on file in office of Coleman Woodbury, University of Wisconsin. Bettman argued that the cost of relocation should be treated as an operating or construction expense and that provisions governing relocation did not belong in an urban redevelopment bill. See also the floor exchange between Bettman and Mrs. Wurster at a planning conference. AM. Soc'y of Planning Officials, Planning 1943, at 103-06. Mrs. Wurster, an influential urban housing specialist, opposed Bettman's point of view.

4342 U.S.C. $\$ 1455$ (c) (Supp. I, 1966).

44 Although it is not really a planning question, the impact of city planning on land acquisition costs in slum areas was frequently discussed in the developmental period of the urban renewal program. The planning process in urban renewal was viewed as a method of preventing the increase in acquisition costs which might result from land speculation; how this result was to be achieved, however, was never fully explained. See, e.g., Report of the Committee on Urban Redevelopment, in Axr. Soc'y of Planning Officials, National Conference on Planning 250, 262 (1941); Letter from Alfred Bettman, supra note 42, at 7, 8. This idea is also implicit in the Thomas bill. S. 953, 79th Cong., 1st Sess. preamble, c1. 1 (1943).

There is some indication that the federal subsidy was accepted, in part, as an alternative to a broader program, which would have led to the "write-down" of acquisition costs. Sec Greer, State and Federal Aid for City Replanning, in Aar. Soc'y of Planning Officials, National Conference on Planning 101 
plan be related to the community plan; ${ }^{45}$ however, planners have failed to define the goals which the planning process was meant to articulate in the redevelopment context. Except for emphasis on slum clearance objectives unrelated to housing, ${ }^{46}$ indications of the goal-setting role of planning are difficult to find.

Alfred Bettman, who was instrumental in drafting some of the early state and federal model urban renewal legislation, and who was influential in planning law circles between World Wars I and II, typifies the early planner's point of view. ${ }^{47} \mathrm{He}$ saw city planning in physically functional terms. ${ }^{48}$ The planning process would "discover" the proper functional form of the city, and planning for redevelopment in slum areas would be part of this discovery process. Bettman does not tell us, however, what problems are to be studied as part of the redevelopment program. His faith lies more in planning as a process than in the use of planning to articulate community goals. In his writings and public statements, ${ }^{40}$ he expresses hope that planning

(1942). It also was recognized that redevelopment planning should not be influenced by a need for high prices in the sale of project land. G. GreER \& A. Hansen, URBAN REDEVELOPMENT AND Housing, supra note 34, at 11. The National Housing Agency's postwar planning committee, however, had expressed concern that project land be sold at the highest possible price in order to minimize the federal subsidy. Notes on Meetings, National Housing Agency, Post-War Comm., June 9, 1943.

45 See note 4 supra.

46 The Senate hearings on post-war economic policy, particularly testimony by Bettman, and an exchange between Bettman and Senator Taft, illustrate the extent to which Bettman and the planners viewed the planning requirement as implementing non-housing objectives in urban redevelopment. Post-War Hearings 1606-07, 1614-18. The report which followed the hearings emphasized the housing element in slum clearance, and proposed the limitation to residential clearance or residential reuse, discussed at text accompanying note 18 supra, which was to find its way into the federal law as enacted in 1949. Senate Subcom. on Housing and Urban Redevelopment, 79th Cong., 1st Sess., Report to the Special Comar. on Postwar Economic Poltcy and Planning 17 (1945). See also Foard \& Fefferman, Federal Urban Renewal Legislation, 25 LAw \& Contemp. ProB. 635, 662-72 (1960).

The reasons for the differing emphasis of the housing experts and planners are traced in Blucher, The Share of the Planner and the Lareyer, in Rehabilitation of the Blighted District, supra note 22, at 75-76; National Ass'n of Housing Officials, 15th Annual Meetings Proceedings Summarized, 5 J. of HousING 315, 330 (1948) (summarizing a talk by planner Paul Oppermann). The Association, which began as the organization of housing authority professionals, was renamed the National Association of Housing and Redevelopment Officials following the enactment of the federal urban redevelopment law. Woodbury Interview.

47 Bettman was the first president of the American Society of Planning Officials (ASPO), a nationally influential organization of planners, lay planning commission members and other professionals and nonprofessionals associated with the planning movement. Planning and the Lawyers, 3 Axs. Soc'y of Planning OfFiciars NEWSLETTER 37 (1967). Bettman chaired an ASPO committee on urban renewal during the years between the world wars.

48 Bettman, Housing Projects and City Planning, supra note 26, at 207-08. 49 See, e.g., Bettman's statement that

We must know what to do with the land before the municipality shall have the legal power to acquire .... The plan is made a requisite of the power to assemble the land simply because the city should not have general, unlimited power to buy the land or to get money from the Federal Government just to buy land. 
can provide rationality in the selection and redevelopment of slum clearance areas. $\mathrm{He}$ is not willing to allow a selection of project areas without a guiding plan prepared in advance. He offers little else.

Lying behind Bettman's attitudes, and behind much of the discussion of the role of planning in urban renewal, is the conventional view of city planning as a coordinating function..$^{50}$ Through the planning process, urban renewal would systematically be coordinated with the city's circulation system, arrangement of land uses and public facilities. Unfortunately, an emphasis on the coordinating function of comprehensive planning occasionally leads to random fact-gathering with no apparent purpose. ${ }^{51}$

In early examinations of the decision-making role of planning, the political decision-makers were also largely ignored, although the federal legislation clearly involves the political structure by requiring a series of local legislative findings in the slum clearance program. ${ }^{52}$ Instead, discussions of planning focused on the stage at which project planning should be carried out, and on the agency which should exercise the planning function. Bettman and others who considered the problem of timing had insisted not only that a general community (and often a neighborhood) plan be prepared before beginning a slum clearance project, but that the plan for project redevelopment be prepared even prior to any steps leading up to the acquisition of project land. ${ }^{53} \mathrm{~A}$ determination on project redevelopment at the planning stage, even prior to land acquisition, would permit a more objective consideration of redevelopment needs than is possible when planning decisions are influenced by the attractiveness of individual projects.

Some early slum clearance laws had authorized the preparation of redevelopment plans by private redevelopment companies, with

50 See, e.g., Report of the Comm. on Urban Redevelopment, in Ax. Soc'y of PlanNing Officials, National Conference on Planning 250, 254 (1941); Bettman, Housing Projects and City Planning, supra note 26, at 206; Office of the Administrator, National Housing Agency, Land Assembly for Urban Redevelopment 33 (National Housing Bulletin No. 3, July, 1945).

51 See, e.g., Planning a Housing Program, in Am. Soc'y of Planning Offrcials, National Conference on Pianning 13 (1938).

5242 U.S.C. $\$ 1455$ (a) (1964), requires findings: that federal financial aid is necessary; that maximum opportunity to participate is afforded to private enterprise; that the renewal plan conforms to a community plan; that the renewal plan
gives consideration to provision of park and recreational facilities.

53 See Report of the Comm. on Urban Redevelopment, in AM. Soc'y of PLANNing Officials, National Conference on PLANning 250, 254-55 (1941) (planning agency must determine "general features" of redevelopment plan); Report of the Comm. on Urban Redevelopment, in AM. Soc'y of PLANNING OFFicials, NATIONAL CoNFERENCE ON PLANNING 166, 175 (1942) (master planning of city must be carried to "the more detailed planning of the redevelopment of any area"); Greer, State and Federal Aid for City Replaning, in AN. Soc'y of PLAN'); OfFicials, NATIONAL ConfrRence on Planning 101, 103 (1942); Grant, sipra note 26 , at 203; HANDBOOK ON URBAN REDEVELOPMENT, supra note 26, at 69 ; Bettman, Housing Projects and City Planning, supra note 26 , at 209. 
the city planning agency only passing on project acceptability as measured against a general community plan. ${ }^{54}$ Bettman found this approach objectionable, ${ }^{55}$ and insisted that community and project planning be done by the planning agency in order to ensure public control of redevelopment initiative. To secure impartiality in the planning process, he also rejected suggestions that the redevelopment authority, be it the housing authority or some other agency, be charged with the planning function as well. ${ }^{58}$ An urban renewal authority, in its role as an entrepreneur in the sale of project land, might try to sacrifice community planning objectives. Community well-being would better be served by placing the planning function in a planning department. ${ }^{57}$

The importance of the urban renewal agency's role in carrying out the project plan was but dimly seen when urban renewal legislation was first considered, and little if any thought was given to the legal framework within which the sale of project land would be conducted. Yet the legal controls governing this step in the redevelopment process directly influence the possibility that the urban renewal plan will be followed faithfully. Implementation of project objectives must depend for its success on the response of the private market and, if the market responds poorly, the project plan might be distorted to get a better market reaction. Statutory insistence in some states on competitive bidding procedures in urban renewal land disposition hides this important reality. Nor were St. Louis and Nashville entirely successful in handling the sale of project land in the absence of a competitive bidding requirement.

54 Office of the Administrator, Urban Dev. Division, National Housing Agency, A Summary of Studies and Proposals in the U.S.A. on Assembly of Land for Urban Development and Redevelopment, app. B, at 13-16 (National Housing Bulletin No. 14, Sept., 1944).

55 Bettman, Urban Redevelopment Legislation, supra note 37, at 112; Report of the Comm. on Urban Redevelopment, in AM. Soc'y of PlanNing Officials, PlanNING 1943, at 93, 94 (Bettman, chairman).

56 See, e.g., Bettman, Urban Redevelopment Legislation, sulpra note 37, at 112; REPoRt TO THE SPECIAL CoMm., supra note 46, at 18; Greer, Urban Redevelopment and Housing 5 (Policy Comm. Memorandum of Div. of Defense Housing Coordination, Office for Emergency Management, Executive Office of the President, July 30, 1941).

57 An even more extreme proposal, which would have conferred the slum clearance function on planning agencies, was considered at one time in the wartime housing agency, but never seriously proposed. Fischer, Preliminary Report on Federal Aid to Urban Land Acquisition 55 (Urban Studies Div., National Housing Agency, March 7, 1944). This proposal had come from the National Association of Real Estate Boards. See National Ass'n of Real Estate Boards, Memorandum of the Program of the Comm. on Housing and Blighted Areas 2 (May 1, 1941). The effect of splitting planning and acquisition powers was not appreciated at the time. This division of responsibility was incorporated into the urban renewal program as it finally evolved. 


\section{The Evolution of Urban Renewal Legislation}

Slum clearance concepts came to maturity just as World War II intervened to prevent their implementation. But interest revived as the war drew to a close and both Congress and state legislatures recognized the need for enabling legislation. Federal legislation was prompted by the need for a federal subsidy for land acquisition costs in slum areas. State legislation was needed primarily to enable appropriate local public agencies to engage in urban renewal programs, since the planning function had already been authorized at the state level in earlier laws. ${ }^{58}$ Several state legislatures passed slum clearance laws before Congress finally acted in 1949; this early state legislation provides a clue to the meaning of the federal planning requirement, as it was finally adopted.

Two model state slum clearance statutes had been available to draftsmen during this period. One, an act drafted by Bettman and published in 1943 by the American Society of Planning Officials, ${ }^{69}$ did not provide for an independent slum clearance authority. Municipalities were authorized to acquire blighted land ${ }^{60}$ and freely to convey the cleared area in its entirety to a specially organized redevelopment corporation. ${ }^{6 \mathbf{z}}$ Not only was conformance to a general plan required, but the preparation of a community plan and a detailed project plan were statutory prerequisites to acquiring blighted areas, unless the project was shown on a master plan or similar report. ${ }^{62}$ In 1945 and 1946, several state legislatures adopted statutes containing planning requirements fashioned on the Bettman draft. ${ }^{63}$ Bett-

58 Much state planning enabling legislation was derived from a model act which had been proposed by an advisory committee of the United States Department of Commerce in 1928. United States Dep't of Commerce, A Standard City PlanNING ENABLING ACT (1928). Bettman served on the advisory committee. The model act did not explicitly authorize planning for slum clearance projects, but did not preclude it. Id. at 15 n.35.

58 Bettman, Draft of an Act for Urban Dev. and Redevelopment (American Soc'y of Planning Officials, March 15, 1943) [hereinafter cited as Draft Act]. See Bettman, Federal and State Urban Redevelopment Bills, in AMr. PranNING AND Civic Ass'n, American Planning and Civic Annual 166 (1943) (in which Bettman recognizes the statutory importance of the "project area" concept).

60 Draft Act, $\$ 7$.

61 Draft Act, $\$ 9$.

62 Draft Act, $\$ 8$. The development plan for the project area was to indicate "the definite and specific locations and extents of the land uses proposed ...." Id. $\S 8(\mathrm{c})$.

63 Ch. 1326, §§ 18-24, [1945] Cal. Laws 2482-84 (redevelopment plan to contain a "general statement of the land uses"); ch. 228, $\$ 4,6$, [1945] Colo. Laws 619,620 (planning provisions not as complete as in Bettman draft); no. 344, $\$ 4$, [1945] Mich. Acts 639 (Bettman planning provisions much abbreviated); ch. 1802, $\$ \$ 19-25,[1946]$ R.I. Acts 368-72 (almost identical to California); ch. 519, § 5 (a), [1945] Wis. Laws 929. Also of interest is the law which Congress enacted for the District of Columbia. District of Columbia Redevelopment Act of 1945, ch. 
man's ideas, however, were not universally accepted. Other states required planning commission approval of the project plan, without explicitly requiring planning commission involvement in the project planning process. ${ }^{64}$ Still others insisted only that the urban renewal project plan "conform" to the general plan for the locality," foreshadowing the federal law.

The National Public Housing Conference, political lobby for the public housing authorities, provided an alternative model ${ }^{\mathbf{6}}$ which deemphasized the planning function. This model gave slum clearance responsibility to the local public housing authority, did not contain a planning requirement and merely provided that the urban renewal project plan must "indicate" its relationship to local land-use and related objectives. In one jurisdiction where this model was adopted, the "indicate" language has since been judicially interpreted to preclude the imposition of anything approaching a community plan requirement. ${ }^{67}$ Several southern states adopted the public housing draft in their 1945 and 1946 legislative sessions. ${ }^{68}$

736, 60 Stat. 790. Although Bettman assisted in the drafting of this statute, see Elimination of Alley Dwellings, Hearings on H.R. 4819, H.R. 4847, and H.R. 4850 Before the Subcommittee on the Judiciary of the House Committee on the District of Columbia, 78th Cong., 2nd Sess. 76 (1944), it significantly departs from the original Bettman model. Only the "approximate" location of land uses need be shown, ch. 36, $\$ 6(\mathrm{~b})(\mathrm{s}), 60$ Stat. 794 , and the neighborhood plan called for by the Bettman draft is not required.

64 Ch. 33, §113 [1945] Conn. Laws 47; ch. 1012, §1, [1945] Md. Laws 1763. Under the Connecticut law, preparation of a comprehensive plan showing redevelopment areas was optional with the planning agency.

65 Ch. 276, § 13, [1945] Ind. Acts 1230-31; ch. 574, pt. IV, [1946] Mass. Acts 639 ; no. $385, \S 10(\mathrm{~b}),[1945] \mathrm{Pa}$. Laws 998 . For an interesting early provision in a law authorizing redevelopment projects to be carried out by redevelopment companies, see ch. 52, \$5(a), [1946] N.J. Laws 111-12. The latest federal draft bill contains similar language, echoing the federal comprehensive planning requirement. Draft Bill, supra note 24, §6(d) (2).

66 The authorship of this bill has been attributed to William J. Guste, a New Orleans attorney who was chairman of the Legislative Committee of the National Public Housing Conference. Woodbury Interview. See Testimony of William J. Guste in Post-War Hearings 1698; Testimony of William J. Guste, in General Housing Act of 1945, Hearings on' $S .1592$ Before the Senate Comm. on Banking and Currency, 79th Cong., 1st Sess. 650-58 (1945 \& 1946).

67 See Runnels v. Staunton Redev. \& Housing Authority, 149 S.E.2d 882, 888 (Va. 1966) :

[Statutory use of the word "indicate"] does not require, however, that a redevelopment plan relate to all the community interests listed in that clause. . By failing to refer to recreational facilities and certain other community interests . . the Plan indicates that it has no relationship to such community interests. Indeed, one would not reasonably expect that a plan directed to the redevelopment of an area for commercial uses would have relation to all the community interests listed in [the statute].

68 Act 212, §4, [1945] Ark. Acts 494-95; ch. 23077, no. 563, §4, [1945] Fla. Laws 1248; no. 616, §5, [1946] Ga. Laws 160; no. 531, \&5, [1946] S.C. Acts 1453; ch. 114, \& 4, [1945]. Tenn. Laws 356; ch. 185, \&1, [1946] Va. Acts 279. These statutes use almost identical language in the planning requirement. Other statutes simply authorized municipalities to carry out the slum clearance function, and contained no planning provisions whatsoever. E.g., ch. 887, [1945] N.Y. Laws 2026. 
In the meantime, policy committees of the wartime housing agency had been considering the content of a possible federal law. The federal agency inherited the ideas that had been developed in the pre-war period, and a concept of the planning role in urban renewal consistent with the prewar approach emerges from its discussions. The agency stressed both the role of planning as a coordinating device, ${ }^{69}$ and the need to center planning initiative in a public agency, which is free of responsibility for implementation. ${ }^{70}$ Attention was given to the function of the federal agency in reviewing community plans, should such plans be required, but emphasis was placed on the adequacy of the local planning process rather than the substantive content of the planning document. ${ }^{71}$ Planning was viewed as an ongoing activity, in which community development objectives should never be frozen by a fixed, unchanging plan. ${ }^{72}$

Slum clearance bills first appeared in Congress in 1943 and were drafted outside the federal agency. ${ }^{73}$ One bill, introduced by Senator Thomas, ${ }^{74}$ and written in part by Bettman, ${ }^{75}$ incorporated the community and project planning requirements of Bettman's model for state legislation and made them a prerequisite to federal aid for slum clearance projects. ${ }^{78}$ The Thomas bill, and others, stimulated interest in urban renewal legislation and led to extensive Congressional hearings, ${ }^{77}$ followed by conferences and discussions inside the na-

Early state legislation is reviewed in Mott \& Wehrly, State Legislation for Urban Development, in AMrerican Civic ANd Planning ANnual 94 (1945); A Summary of Studies and Proposals in the U.S.A. on Assembly of Land for Urban Development and Redevelopment, supra note 54 .

69 Land Assembly for Urban Redevelopment, supra note 50, at 33.

70 Id. at 34 ; Greer, supra note 56 , at 5.

71 See Howard, Selected Materials From the Discussions of the NHA [National Housing Agency] Postwar Comm. 10 (Sept. 20, 1943). Where "adequately prepared" local plans did not exist, the committee had considered preparation by the federal agency of a "locality housing report" to encompass some elements of the local planning process and guide the federal agency's activities. Id. See also Crane, Memorandum on Questions 6 and 14 in Woodbury's Statement of April 3, 1943, at 2 (April 10,1943), in Howard, supra. See a later report by a subcommittee of the American Institute of Planners, in which Crane reflected an extremely vague perception of the role of local planning in slum clearance. A Subcomm. Report to the Board of Governors of the American Institute of Planners, Principles for Federal Urban Redevelopment Legislation (Oct.-Nov. 1947).

72 Comments on C.U.R.A. Proposal 2 (Division of Defense Housing Coordination, Office for Emergency Management, Executive Office of the President, September 17, 1941).

73 Woodbury Interview. For a general review of the history of federal housing legislation during this period, see R. DAvies, Housing Reform During the Truman ADAIINISTRATION (1966).

74 S. 953, 78th Cong., 1st Sess. (1943).

75 See note 18 supra.

76 S. 953, 78th Cong., 1st Sess. $§ 12$ (1943).

77 During the hearings, Senator Robert Taft was very skeptical of the use of slum clearance powers for other than housing purposes. See, e.g., Post-War Hearings 1558. Senator Taft later moderated his views somewhat. See Hearings on Bills 
tional housing agency that produced an Administration housing bill with a slum clearance title. This bill ${ }^{78}$ contained planning requirements substantially similar to those eventually adopted in 1949 after a long political struggle. ${ }^{79}$

As finally enacted, the federal provision on community planning for slum clearance stripped the detailed language that had been contained in the Thomas bill and borrowed from state legislation to impose the requirement of a local legislative finding that the urban renewal project plan "conforms to a general plan for the development of the locality as a whole." 80 The effect of this provision is quite limited. Since the statute speaks of a "legislative finding," not of the general plan itself, a court asked to review for conformity to the provision plausibly could refuse to look behind the legislative determination to ascertain whether a general plan actually existed. ${ }^{81}$ Clouding the legislative intent even more, the federal statute borrowed language from the Public Housing Conference draft, and also required the urban renewal project plan to "indicate" its relationship to stated local objectives. ${ }^{82}$

Pertaining to Honsing Before the Senate Comm. on Banking and Currency, 80th Cong., 1st Sess. 10 (1947). Noting that he first intended to confine the bill to residential slums, he added that "the slums are all mixed up with the rest of the blighted areas." Id.

78 S. 1592, 79th Cong., 2d Sess. $\S 603(3)$ (1946).

79 The bill required a finding by the local governing body that " $[t]$ he redevelopment plan is based upon a local survey and conforms to a comprehensive plan for the locality as a whole." Id. This was the first bill that Senator Taft joined as sponsor, and clearly had its origins in the work of the special 1945 Senate subcommittee on urban redevelopment and in a series of discussions in the federal housing agency in which several Senators, including Senator Taft, participated. Woodbury Interview. See also General Housing ACT of 1946, S. REP. No. 1131, 79th Cong., 2d Sess. 2 (1946). Apparently Senator Taft did not make any significant changes in the substantive content of the legislation. Woodbury Interview.

A housing bill introduced in the previous session by Democratic Senators Robert Wagner and Allen Ellender had contained a weakened version of the comprehensive planning requirement, requiring a finding by the local governing body that " $[t]$ he redevelopment plan is based upon a local survey of the redevelopment needs of the locality as a whole." S. 1342, 79th Cong., 1st Sess. \$303(3) (1945). When the housing bill was reintroduced in 1947, following its defeat in the House of Representatives in 1946, it contained the planning provision in its present form. S. 866, 80th Cong., 1st Sess. $\$ 802(1)$ (1947).

8042 U.S.C. $\$ 1455$ (a) (iii) (1964).

81 Cf. Moskow v. Redevelopment Authority, 349 Mass. 553, 567-68, 210 N.E.2d 699, 708 (1965).

82 Housing Act of 1949 , ch. $338, \S 110$ (b), 63 Stat. 420 (now 42 U.S.C. $\S 1460$ (b) (1964)). Later changes in this section have confused its meaning even further. In 1954, a provision was added to the definition of an urban renewal plan which required it to "conform to the general plan of the locality as a whole," thus using the language also found in the section requiring a local legislative finding to the same effect. Housing Act of 1954, ch. 649, §311, 68 Stat. 626. The definition was subsequently expanded to require that the urban renewal plan also "be consistent with" local objectives relating to land use and other factors. Housing Act of 1957 \$ 305, 71 Stat. 301 (1957). The 1957 change was not intended as a requirement that the renewal plan conform to or comply with local objectives stated in a comprehensive plan, Housing ACT of 1957, S. Rep. No. 368, 85th Cong., 1st Sess. 21 (1957), but rather to 
In its provisions on the sale of project land, the statute required that the land be sold at its "fair value" in accordance with the uses as shown on the project plan. ${ }^{83}$

One participant in the legislative process leading up to the enactment of the federal urban renewal law has described the planning provision as a "weak compromise," 84 in which planning was given a role to play in urban renewal-but not a crucial one. First-round slum clearance projects would, in any event, tackle the "obvious" slums. Planning was needed when reuses were nonresidential, and here displaced site residents would be protected by the relocation requirement. Once experience was gained under the program, the planning provisions of the statute would be redrafted. But redrafting on a meaningful scale has not occurred, ${ }^{85}$ and resolution of the ambiguities in the federal statute has devolved upon federal and local administrative agencies.

\section{Federal Administrative Implementation of the Planning Requirement}

With the passage of the National Housing Act of 1949, the federal housing agency was faced for the first time with the need to implement nationally a city planning requirement. ${ }^{86}$ Draftsmen of

permit a local community to indicate in a submission separate from the urban renewal plan, the relationship between the urban renewal plan and overall local planning objectives. As now worded, the statute requires this relationship to be indicated in the urban renewal plan itself, which has caused administrative inconvenience for some communities.

Id. A provision in the 1949 act also required that the federal agency attempt "to assure consistency between the redevelopment plan and any highways or other public improvements in the locality receiving financial assistance." This provision was dropped in 1954. Coordination with highway programs is still required by administrative regulation. U.S. HousING AND HoMe FINANCE AGENCY, URBAN Renewal Administration, Urban Renewal Manual $\$ 10-1$, at 2 (June 29, 1965) [hereinafter cited as CURRENT MANUAL]. The federal urban renewal agency is now known as the Renewal Assistance Administration of the Department of Housing and Urban Development (HUD).

The definition of the redevelopment plan in the 1949 act can be traced to the first slum clearance bill introduced by Senator Wagner. See S. 1163, 78th Cong., 1st Sess. $\$ 2(3)(1943)$.

8342 U.S.C. $\$ 1460$ (c) (4) (1964).

84 Woodbury Interview.

85 See note 72 supra.

86 The following discussion of the federal administrative regulations relies heavily on M. Berger, Federal Implementation of the Planning Requirement in Urban Renewal, 1967 (unpublished manuscript on file in Washington University Law Library).

The federal manuals and administrative regulations which guide the urban renewal program have undergone several important modifications. Administration of the slum clearance program was placed initially in a division of the Office of the Administrator of the Housing and Home Finance Agency, which issued a relatively brief administrative guide to the slum clearance program. United States Housing and Home Finance Agency, Division of Slum Clearance and Urban Redevelopment, A Guide to Slum Clearance and Urban Redevelopment Under Title I of the Housing Act of 1949 (1950). In 1951 this guide was replaced by a more complete manual 
the initial administrative regulations indicated ${ }^{87}$ that local flexibility in carrying out the planning requirement was encouraged intentionally by concentrating on the planning process rather than on the operational criteria for important planning decisions. ${ }^{88}$

Federal administrators were all too aware of the limitations and ambiguities surrounding city planning. ${ }^{89}$ They wisely insisted that city planning as a continuing process be emphasized in preference to the completion and adoption of a community plan which might grow out of date. ${ }^{90}$ But their most crucial decision affected the timing of project planning as it relates to the general plan. Their regulations ${ }^{91}$ provided that the general plan need not be complete when project planning was initiated, ${ }^{92}$ and that the general plan need be finished only when the final plan for the project was submitted to the federal agency. ${ }^{93}$ This decision was directly opposed to Bettman's recommendations. Bettman had insisted, and the earlier Thomas bill had provided, that detailed project planning in accordance with a general

for urban renewal agencies, called Local Public Agencies (LPA). UNItEd STATES Housing and Home Finance Agency, Urban Renewal Administration, Urban Renewal Manual: Policies and Reguirements for Local Public Ágencies (1951) [hereinafter cited as IPA MANUAL]. The 1951 manual was subsequently modified by a letter to the local public agencies which included changes made necessary by the Housing Act of 1954 which extended the slum clearance program to include rehabilitation projects. United States Housing and Home Finance Agency, Urban Renewal Administration, LPA Letter No. 45 (December, 1954). The letter itself was amended several times before it was superseded by the issuance of a new manual in 1959. This manual was in turn superseded by the Urban Renewal Manual which is currently in force. See note 82, supra. Local Public Agency (LPA) letters are still issued by the federal agency to provide supplementary guidance in the administration of the program, and to make new regulations more quickly available before they are permanently incorporated in manual form.

The discussion which follows is based on federal regulations in force from 1951 through 1959, which were applicable to the St. Louis and Nashville projects discussed in this article.

87 Feiss, Urban Redevelopment and Urban Planning, in Am. Soc'y of PlanNing Offictals, Planning 1950, at 16; Zisman, The General Plan in the Redevelopment Program (National Ass'n of Housing Officials, Redevelopment Information Serv., Special Publication No. 5, November, 1952).

88 Feiss, supra note 87 , at 23 ; Zisman, supra note 87 , at 4 .

89 Feiss, supra note 87 , at $21-23$.

90 Id. at 23 ; Zisman, supra note 87 , at 4 .

91 Most of the manual citations in this are to the LPA Mantal in the form that it existed just prior to issuance of the new manual in 1959. It has been noted that the federal regulations were in some confusion during the 1951-59 period because of the existence of uncollated letters and directives in addition to the official manual. Interview with John Shively, Urban Renewal Administration, in Washington, D.C., September 1, 1965.

92 LPA MANUAL $\$ 2-2-3$, at 1 (February 2, 1955). This provision has since been changed so that compliance with the community planning requirement is now ordinarily determined by checking the latest Workable Program submission. CURRent Manual \$2-2; at 1 (April 25, 1960). The Workable Program requirement was added in 1954 as a means of encouraging local communities to adopt programs to prevent and inhibit the spread of blight. 42 U.S.C. \$1451(c) (Supp. I, 1966). It has been administratively interpreted to require preparation of a community plan.

93 LPA MANUAL \$2-2-4, at 2 (May 5, 1955). 
plan precede the decision to give federal assistance. Now planning for individual projects could begin before the general plan was even adopted. By deferring the completion of the general plan until the submission of the final project plan, the federal agency allowed the content of the general plan to be influenced by ad hoc redevelopment decisions. $^{94}$

Nor were the criteria governing project selection clearly indicated. While the general plan was to determine project priorities, ${ }^{95}$ criteria for establishing these priorities were not given. Much emphasis was placed on the need to pick project areas conforming to administratively determined definitions of blight and deterioration, ${ }^{96}$ but project selection predicated on degrees of blight was not in any way related to the implementation of goals articulated in the general plan. These ambiguities were compounded by setting very low threshold blight standards, ${ }^{97}$ by listing factors affecting project selection without indicating which criteria were to have priority ${ }^{98}$ and by insisting that

94 A lengthy, heavily documented planning process is required prior to federal acceptance of the redevelopment plan contained in a final project report. Projects are initiated by a Survey and Planning Application which requests federal funds for a planning advance. Current Manual \$ 4-1-1 (March 30, 1964). During the period in which the Nashville and St. Louis projects were planned, a Preliminary Project Report was also required prior to the submission of the Final Project Report. LPA Manual \$2-1, exhibit \#1 (May 1, 1951). The Preliminary Report was reduced in scope and finally eliminated following a review of urban renewal procedures by a task force in the federal agency in 1956. Report of the Procedures Simplification Task Force 3, 4 (April 16, 1956). See LPA Letter No. 194: Revised Urban Renewal Manual 1 (March 7, 1960). The reason for the change was that the interim project report required unnecessary documentation in a planning process that was viewed as continuous.

85 LPA Manual $\S 2-2-2$, at 1 ; $\$ 2-2-3$, at 2 (Feb. 2, 1955). See also Feiss, supra note 87 , at 27 ; Zisman, supra note 87 , at 7 .

96 LPA MaNUAL § 2-4-2, at 3, 4 (Jan. 24, 1956).

97 The 1954 administrative requirements for a slum clearance project were that twenty percent of the residential structures must 1) need major repair or be deficient in plumbing or heating facilities; or 2) be in a poor state of repair; or 3) be converted to excessive densities or to incompatible types of living accommodation, e.g., rooming houses among family dwellings. The low qualifying proportion could thus be satisfied by overcrowding and incompatible land-uses as well as by physical deterioration. In addition, at least one of six environmental deficiencies had to be present. These deficiencies included narrow and crooked streets, overcrowding, overoccupancy and mixed uses. The area could still qualify, even in the absence of physical deterioration, if three environmental deficiencies were present. U.S. Housing and Home Finance Agency, Urban Renewal Administration, LPA Letter No. 45, 1-4 (December, 1954).

These qualifications were sufficient to establish an "urban renewal" area. To establish a slum clearance and redevelopment "section" within an urban renewal area, it "must be shown to require slum clearance and redevelopment because rehabilitation would be impractical or ineffective, or because slum clearance and redevelopment is necessary to achieve planning objectives." Id., \$1-5 (emphasis added). It should be noted that most renewal planners will call for clearance only if fifty percent or more of the structures in the area are substandard. These blightrating techniques in the federal regulations are primitive and over-simplified. See, e.g., Central Planning Board of Newark, N.J., Re: New Newark 118-30 (1961).

98 Ten factors were listed "which influence the delimitation of project areas on the setting of priorities." LPA MANUAL \$2-4-1, at 1 (Feb. 11, 1953). These factors 
project redevelopment be justified more by potential marketability than by city planning considerations. ${ }^{99}$ Difficult problems in the application of these directives were left to local slum clearance authorities.

\section{Sium Cifarance in Nashville: The Capitol Hill Project The Setting}

Strategically located in the mid-south, the state capital and a rapidly growing city ${ }^{100}$ in a metropolitan area of 350,000 , Nashville presented a classic example of an urban renewal program conducted by a well-established public housing authority, operating in a legal environment in which few formal planning restraints were imposed.

The metropolitan consolidation of the city and county, which has attracted national attention, came after the period covered in this study. It did not affect the early urban renewal program, and urban renewal was not a factor in the creation of the metropolitan government. In this article, the focus of the discussion is on the city of Nashville as it existed prior to the consolidation. ${ }^{101}$

The legal basis for slum clearance in Nashville is of central importance and will be considered first, for the Tennessee law ${ }^{102}$ was

include such partially inconsistent criteria as severity of blight, feasibility of redevelopment and "relation of the project area under consideration to the general plan." The manual also states that "not all of the above factors will require equal consideration in all situations." Id. One of the draftsmen of the first federal regulations also had emphasized the importance of population distribution and economic analysis in urban renewal planning. Feiss, supra note 87 , at 24.

99 See LPA MANUAL \$2-5-3, at 7 (Aug. 26, 1955), requiring the Final Project Report to show "the extent of private enterprise interest in the proposed development." This statement was to appear as part of a "Report on Economic Soundness of Proposed Land Uses." Only residential reuses were to be discussed in relation to "the provisions of the general plan of the locality." Id. at 5. It was not until 1960 that land utilization and marketability studies were explicitly required. U.S. Housing and Home Finance Agency, Urban Renewal Administration, LPA Letter No. 194, at 2 (March 7, 1960).

100 The Nashville metropolitan area grew by 24 percent between 1950 and 1960 .

U.S. Advisory Comm'n on Intergov., Relations, Metropolitan Soctal and ECONOMIC DISPARITIES: IMPLICATIONS FOR INTERGOVERNMENTAL RELATIONS IN CENtRal Cites and Suburbs 221 (Jan., 1965) [hereinafter cited as Disparities]. The Nashville area growth figure, while significant, was below the national average of 32 percent for 190 Standard Metropolitan Statistical Areas. Id. at 229. A more recent evaluation of the Nashville area bears quoting:

Here is an area with an advanced form of new local government and with outstanding economic prospects, but it faces sharp issues-rising demands for services, rising pressures on municipal costs, increased need for rebuilding as well as expanding, restricted revenue sources, and possible losses of economic functions and new investments to outlying areas. Few metropolitan centers have a more auspicious future and few have a more difficult set of problems to solve.

Hammer \& Company Associates, The Economy of Metropolitan Nashinle 189 (Nov. 1963).

101 Experience with metropolitan government in Nashville is summarized in Grant, $A$ Comparison of Predictions and Experience with Nashville "Metro," 1 URBAN AfFaIRS Q. 35 (1965).

102 Ch. 114, §2-9, [1945] Tenn. Laws 354 (now Tenn. Cone Ans. §\$13-813 to -820 (1955)). Tennessee subsequently passed another law in 1955 authorizing 
based on the draft proposed by the Public Housing Conference and contains little in the way of a formal planning structure. Independent urban renewal authorities had been recommended by proponents of the urban renewal idea, apparently to separate the slum clearance program from public housing. ${ }^{103}$ The Tennessee law not only conferred operating responsibilities on public housing authorities, but contained no formal planning provision. Project selection was based on the identification of blighted areas, which were defined conventionally in physical terms. ${ }^{\mathbf{1 0 4}}$ Competitive bidding was not required in the sale of project land, which could be sold or leased "for uses in accordance with the redevelopment plan" ${ }^{105}$ at a value "at which the

housing authorities to undertake rehabilitation as well as slum clearance projects. TEnN. Code ANN. \$\$ 13-821 to -827 (Supp. 1966).

Gerald Gimre, Executive Director of the Nashville Housing Authority, discussed the Tennessee redevelopment law at the 1945 ASPO meeting. AM. Soc'y of Planning Officials, Planning 1945, at 56. Gimre pointed out that while they were not satisfied with the planning requirements of the National Public Housing Conference draft, "We agreed that, since the act requires the preparation of a redevelopment plan which must be approved by the city's legislative body, any planning commission through its own powers could guide the planning of any municipal redevelopment scheme." Id. Gimre added that there would in fact be informal cooperation between the planning and redevelopment agencies in Tennessee.

Gimre's contention that the statutory planning structure in Tennessee required planning commission approval of any redevelopment project is not borne out by an examination of the planning law in effect at that time, which included a reference to the "replanning of blighted districts and slum areas" in its description of the general plan. Ch. 34, §3, [1935] Tenn. Laws 65. However, planning commission approval was only required for streets and public works, with no explicit reference to slum clearance projects. Id. \$7, at 66. This statute was drafted by Bettman. Interview with Gerald Gimre, Executive Director, Nashville Housing Authority, in Nashville, Tenn., June 7, 1965 [hereinafter cited as Gimre Interview]. It derives from section 9 of the model planning act, discussed at note 58 supra. A footnote to that section indicates that the provision was inserted primarily to control the construction of public facilities by agencies other than municipal departments, such as school boards. United States Dep't of Comanerce, A Standard City Planning ENABLING ACT 20 n.50 (1928).

103 See, e.g., HANDBOOK ON URBAN REDEVELOPMENT, supra note 26, at 68-69; Mott \& Wehrly, State Legislation for Urban Redevelopment, supra note 68; Urban Redevelopment, in American Soc'y of Planning Officials, Planning 1945, at 43-46. Bettman's model act did not provide for an independent slum clearance agency. Draft Act, supra note 59. By the time he drafted the District of Columbia Law, however, a separate land clearance agency had been provided. See note 63 siepra.

$104 \mathrm{Ch} .114, \S 2$, [1945] Tenn. Laws 354 authorizes housing authorities to acquire blighted areas,

which are hereby defined as areas (including slum areas) with buildings or improvements which, by reason of dilapidation, obsolescence, overcrowding, faulty arrangement or design, lack of ventilation, light and sanitary facilities, excessive land coverage, deleterious land use or obsolete layout, or any combination of these or other factors, are detrimental to the safety, health, morals, or welfare of the community.

(Emphasis added.)

$105 \mathrm{Ch} .114, \S 2(5)$, [1945] Tenn. Laws 354. The Tennessee definition of a redevelopment plan still conforms to the definition originally contained in the federal law, Housing Act of $1949 \$ 110$ (b), 63 Stat. 420 (1949), and only requires that the plan show "land uses and building requirements in the area." TENN. CODE ANN. $\$ 13-815(2)$ (1955). The federal definition has since been substantially changed to require a more comprehensive indication of redevelopment intentions, including 
authority determines such land should be made available in order that it may be . . . redeveloped for the purposes specified in such plan." ${ }^{108}$

While planning judgments do influence the renewal process inasmuch as the redevelopment plan controls the sale of project land, the legal import of the plan is ambiguous. ${ }^{107}$ The redevelopment plan is officially adopted by the Tennessee legislature, ${ }^{108}$ as required by federal law, ${ }^{109}$ and adherence to the plan is an essential condition of federal aid. Under state law, however, the plan has no independent status. It can be recorded as a plat, as in the Capitol Hill project, ${ }^{110}$ and as the federal regulations permit, ${ }^{111}$ in which case the plan has the same legal effect as any subdivision plat. The only controls on the redeveloper are the covenants shown on the plat, implementing a Tennessee statute required by federal law, ${ }^{112}$ that the redeveloper "use the land for the purpose designated in the redevelopment plan . . . [under] obligations by the purchaser [which] shall be covenants and conditions running with the land where the authority so stipulates." 113 Other than the plat, only the local zoning ordinance binds the redeveloper. The Tennessee statute is silent on the problem of coordination between the zoning ordinance and the redevelopment plan, although the federal statute contemplates zoning changes, when necessary, to implement a redevelopment project. $^{114}$ When the language governing the legal effect of the project plan is read together with the language governing the sale of project land, the net effect is to place considerable discretion in the housing authority, both in determining the content of any operable plat covenants and in setting the terms of sale.

In view of this permissive legal structure, the political and professional climate for the conduct of the urban renewal program becomes critical. Although Nashville is located in the middle Tennessee belt which is predominantly Democratic, Nashville city politics were

"zoning and planning changes, if any, land uses, maximum densities, and building requirements." 42 U.S.C. $\$ 1460$ (b) (2) (1964). The definition of redevelopment plan content is important for its potential influence on land disposition decisions and on disposition prices.

108 Ch. 114, § 5, [1945] Tenn. Laws 357.

${ }^{107}$ Cf. Argentine Citizens Committee v. Urban Renewal Agency, $194 \mathrm{Kan}$. 468, 399 P.2d 553 (1965), suggesting that an urban renewal plan becomes an official act of the city following its adoption by the governing body of the municipality. The legal effect of the adoption was left unclear by the opinion.

108 Ch. 114, § 4, [1945] Tenn. Laws 356.

10942 U.S.C. $\$ 1455$ (a) (1964).

110 Nashyille Housing Authority, Restrictive Covenants Running With the Land of the Nashville Housing Authority in the Capitol Hint RedevelOPMENT PRoject 4 (January, 1958) [hereinafter cited as Nashville Covenants].

111 CuRrent Manual $\S 14-2-3$, at 5-6 (Aug. 18, 1965).

11242 U.S.C. $\$ 1455$ (b) (i) (1964).

113 Ch. 114, § 5, [1945] Tenn. Laws 357.

11442 U.S.C. $\$ 1460$ (b) (2) (1964). 
nominally nonpartisan and relatively stable. ${ }^{115}$ Strong personal political machines were led by the incumbent mayor, a dominant political and administrative figure; except for one seven-year period, the mayor's office from 1909 to 1963 was held by only three men. Ben West was mayor while the Capitol Hill project was planned and substantially completed, and his relatively long tenure and interest in urban renewal issues made him a key personality in the Nashville urban renewal program. His influence was reinforced by a strong housing authority, which had acquired substantial operating experience in public housing. The authority has been led by the same executive director since its creation in 1938. Similar continuities marked the planning staff, the planning commission and housing authority board, and two important private agencies, the Chamber of Commerce and the Nashville Banner, one of Nashville's two daily newspapers. Staff moved back and forth between the housing authority and the planning commission, and the two agencies cooperated closely, setting the stage for housing authority dominance of the planning function (a dominance which Bettman and others had feared). Important urban renewal decisions were negotiated among key community and business leaders, technical staff in the housing authority and the planning commission, and the mayor, but the number of principal actors was few. ${ }^{118}$ Public involvement in urban renewal in Nashville was further minimized by the absence of a referendum requirement for urban renewal bond issues and by the greater priorities attached to other public issues during the period under study. ${ }^{117}$

Urban renewal issues should have been important to one segment of Nashville's population-its Negroes. The proportion of Negroes in the city was high, ${ }^{118}$ in spite of a relative decline in nonwhite immi-

115 See B. Hanson, A Report on Politics in Nashville, 1966 (Unpublished thesis on file at Joint Center for Urban Studies, Cambridge, Mass.). A leading student of southern politics has pointed out that the factionalized leadership usually characteristic of the South produces discontinuities in program development, which can be quite harmful, because program decisions are made by individual officeholders who are often repudiated by their successors. V. KEY, SoutherN Polmics 302-10 (Vintage ed. 1949). Key also suggests that the disorganization attendant on factionalized politics also works to the detriment of underprivileged groups, especially Negroes, who may effectively be disenfranchised. Id. at 307. These tendencies were also evident in the urban renewal program in Nashville in the period under study.

116 A similar pattern was uncovered in a close analysis of the renewal program in New Haven, Connecticut. See R. DAHL, Who GoverNs?, Denrocracy and Power in aN AMERICan City 114-40 (paperback ed. 1961).

117 A 1952 review of Nashville and metropolitan area needs devoted only six out of 201 pages to problems of public housing and substandard housing and did not discuss slum clearance at all. REPORT of THE Community Services Commission, A Future of NAshville (1952).

118 In 1960, 38 percent of the population of Nashville was nonwhite. DisPARITIES 222. 
gration from 1950 to $1960,{ }^{119}$ and many of Nashville's extensive slums were inhabited by nonwhites. Nonetheless, as might be expected in the midsouth, the Negro community did not participate actively in urban renewal decisions, although the housing authority board had an apparently quiescent Negro member for a long time. Negro councilmen were also on the city council, where they were able to exercise a strategic veto over slum clearance projects in Negro districts and a marginal influence on Capitol Hill. ${ }^{120}$

Nashville's planning effort up to the time of the Capitol Hill project is difficult to evaluate. No formal plan had been adopted before World War II, although a land-use plan had been prepared in 1933 ; $^{121}$ pre-war studies had focused local attention on the severity of residential blight. ${ }^{122}$ Capitol Hill was initated in 1949, soon after the enactment of the federal law. However, no formal advance planning was carried out in Nashville until 1956. This failure on the part of Nashville's planners to adopt a formal city plan was intentional, and they still resist the more extensive community-wide programming which is now optional in the urban renewal program. In place of a formal comprehensive city plan, Nashville's planners substituted their own familiarity with the city and the informal articulation of planning goals through implicit staff policies.

\section{Selecting and Planning the Capitol Hill Project}

The steep, rocky hill around the Tennessee state capitol, just north of the downtown area, had for years been a highly visible and badly blighted slum which detracted from the architectural splendor of the capitol building and interfered with the expansion of other state facilities on the capitol site. State buildings erected prior to the urban renewal project faced inward, away from the slum district. Moreover, the Capitol Hill slums blocked northward expansion of the business district, and their grid pattern of streets interfered with

119 Hammer \& Company Associates, Fousing Study and Market Analysis of Merropolitan Nashville, Tennessee 6-14 (Nov. 1963). Since the rate of Negro immigration is the most significant factor affecting the rate of racial change in residential neighborhoods, C. TAEUBER \& I. TAEUBER, NEGRoes IN CTTIES 4 (1965), rates of change can be expected to be relatively slow in a city like Nashville in which the Negro immigration rate is low.

120 Negro leadership in Nashville during the Capitol Hill project period was dominated by older leaders with personal followings who reflected the factionalism of Nashville politics. Negro resistance to urban renewal was unsophisticated; one prominent Negro attorney still considers slum clearance for private redevelopment to be unconstitutional.

121 Gimre Interview. The document embodying the plan is not available.

122 Forty-six percent of rental housing in Nashville is unsound, Disparities 223, as compared with a figure of 33 percent for 190 Standard Metropolitan Statistical Areas. Id. at 231. 
traffic flow and created site inadequacies which were noted when the capitol was built in the mid-nineteenth century.

These problems did not escape the planners. Capitol Hill had been considered as a public housing site, but its location and topography ruled out this possibility. When federal assistance for slum clearance became available in 1949, the housing authority saw an opportunity for redevelopment, partly in association with state office development, partly as an extension of the downtown business district and partly as an opportunity to provide a parkway at the base of the site, which would help relieve traffic congestion. Selection of the site was backed by planning commission studies of core city neighborhoods and by a thorough study of housing quality. ${ }^{123}$ For displaced site residents, new public housing was planned.

Political considerations now entered the redevelopment picture. Nashville's mayors were strong, and mayoral opposition to urban renewal would clearly be decisive in spite of the legal independence of the housing authority. Early planning for Capitol Hill, which was carried out just before Mayor Ben West's election in 1950, had stirred Negro opposition. West was wary of a decision that might prove politically harmful. At this point, pressure on the mayor and bargaining with the Negro community saved the project. West was persuaded by the editor and city hall reporter of the Nashville Banner that Capitol Hill was in the city's interest, but only after a boundary compromise was negotiated that satisfied Negro objections. Part of the Negro business district at the southeast corner of the original project area was excluded, and a large headquarters building of a Negro church left standing in the same vicinity. ${ }^{124}$ These changes left a pocket of commercial blight at a key point in the project, limiting redevelopment opportunities by blocking the expansion of the business district. $^{\mathbf{1 2 5}}$

Capitol Hill was approved by the federal agency, although no general plan had been adopted for the city. ${ }^{126}$ In that part of the project submission to Washington in which the relationship of the

123 Nashville Housing Authority, Housing Survey of 1949.

124 This building was subsequently remodeled pursuant to an agreement with the housing authority. The history of boundary changes in the Capitol Hill project is outlined in Starr v. Nashville Housing Authority, 145 F. Supp. 498 (M.D. Tenn. 1956).

125 This area has now been included in a new urban renewal project. NAsHvILIE Housing Authority, ANNuAd Report 13 (1964).

126 However, elements of a general plan were in existence when the application was made for a federal grant. Nashville Housing Authority, Capitol Hill Redevelopment Project, Application for Loan and Grant, Part II (June 23, 1952). Most of these elements related to plans for public facilities, but a thoroughfare plan had also been prepared. 
72-acre project to local planning "objectives" had to be defended, the housing authority relied principally on the improvement of streets and utilities. ${ }^{127}$ Reference was also made to the removal of nonconforming residential uses from a commercial zone, an objective somewhat weakened by the reintroduction of residential uses in the redevelopment stage. More comprehensive planning strategies were not discussed. Nevertheless, the concrete developmental objectives contemplated in the Capitol Hill project were at least plausibly consistent with a comprehensive strategy for the city.

Capitol Hill's role in a comprehensive housing program is less easily defended, and its selection for early clearance illustrates how the qualification of project areas on the basis of physical conditions hides important issues of housing policy. By one measure, threequarters of Capitol Hill's housing was substandard, ${ }^{128}$ and the area easily qualified under federal criteria. But housing on Capitol Hill was not the worst in the city, and its selection for early clearance deferred improvement of Nashville's worst slum, whose clearance would not have improved the downtown business district. ${ }^{129}$ Potential conflicts between local housing policy and local planning policy were thus hidden by the legal requirement that based project selection solely on external physical conditions.

127 Nashville Housing Authority, The Redevelopment Plan for the Capitol Hill Redevelopment Project 6 (rev. draft April 7, 1952). No further draft is available. One of the major purposes of the Capitol Hill project was to remove the inadequate grid pattern of streets that had been imposed on the hill, and to improve circulation by providing a new boulevard at the base of the hill. These improvements were "planned" in the sense that they were based on an area-wide survey of traffic demand. See Nashvinle Housing Authority, Capitol Hill Redevelopment Project 28-31 (1952) (consultant's report). Note must also be taken of the extensive construction of state office buildings which took place in conjunction with the Capitol Hill project. This report does not attempt to detail the state's role in the project. Evidence indicates, however, that the initiative for the project came more from the city than from the state, and that relationships with state officials were sometimes strained.

128 This statement is based on an analysis of the census tract in which the Capitol Hill project is located, which included the project area together with an adjacent downtown section. It can be assumed that all or most of the housing in this census tract was located in the project area. NAsHville Housing AUTHORITY Housrng Survey of 1949, table I, at 17. The survey tended to overstate slum housing conditions. A dwelling was rated substandard if it was deficient for any one of four reasons, including lack of an indoor private toilet, lack of an indoor private bath, lack of adequate heating facilities or need for major repairs. The survey of existing conditions in the project plan indicated that only 4 of 622 dwelling units were in good condition, while 47 needed only minor repairs. Of the rest, 427 needed major repairs and 144 were considered unfit for dwelling use. Redevelopment Plan, supra note 127 , at 3 .

129 The largest Negro slum area in Nashville is the Edgehill neighborhood, which has just recently been scheduled for renewal. City and housing authority officials deferred scheduling Edgehill for renewal, in part, because of the large relocation burden which a project in that area would generate. The Edgehill area was not entirely neglected by the city, however, during the interim period before the renewal project was initiated. 
Racial problems flowing from the Capitol Hill project also require discussion. Capitol Hill, a central Negro residential area, was to be replaced by nonresidential development, and a new public housing project on the west was expected to take many of the site residents. The renewal agency would also attempt to meet Negro relocation needs through housing shifts in neighborhoods which were changing from white to Negro. ${ }^{130}$

The housing authority's approach to the racial issue is ambivalent As of 1965, Nashville had three times as many public housing units per capita as St. Louis, ${ }^{131}$ and by any measure its public housing effort was substantial. Yet Nashville public housing was segregated when Capitol Hill was planned. Negro and white public housing projects were roughly separated along a north-south axis, reinforcing patterns of residential segregation at a time when federal controls over project integration were nonexistent. Against this background, the use of the Capitol Hill project to replace a Negro slum in the center of the city with predominantly nonresidential redevelopment gains in significance. The result might be a qualitative improvement in the Negro housing supply, at the cost of losing a central location. However, the construction of a new public housing project to the west of Capitol Hill to meet the relocation needs of displaced site residents would only intensify racial segregation in Nashville. Even these expectations of qualitative improvement were disappointed. Evidence suggests that most of Capitol Hill's Negroes relocated to substandard housing in the Negro ghettoes. ${ }^{132}$ A high proportion of the site residents were eligible for public housing, ${ }^{133}$ but only one-fourth of those eligible chose to move there. ${ }^{134}$

\section{Redevelopment on Capitol Hill}

While the Tennessee statute is not explicit on the point, ${ }^{135}$ responsibility for the redevelopment plan appears to be lodged with the hous-

130 Application for Loan and Grant, supra note 126, at 3.

131 Nashville had a 1960 population of approximately 170,000, and 4500 public housing units in 1965. NASHVIILE HousING AUtHORITY ANNUAL REPORT 2 (1964). St. Louis had a 1960 population of approximately 750,000, and the St. Louis authority reports 6400 units as of 1966 . However, comparisons are difficult because of changes in population during the period under study and because additions continue to be made to the public housing stock.

132 In 1949, the vacancy rate in standard housing was less than one percent. Housing SuRvey of 1949, supra note 123, at 15.

133 Application for Loan and Grant, supra note 126, at 1. Of 324 Negro families, 244 were eligible for public housing.

134 This experience is not atypical. Hartman, The Limitations of Public Housing: Relocation Choices in a Working-Class Community, $29 \mathrm{~J}$. AM. INST. of PLANNERS 283 (1963) (survey of experience in Boston). Under federal law, relocation responsibility ends when a site resident rejects public housing and moves to substandard accommodations, See CURRENT MANUAL \$16-3-1, at 5 (Feb. 3, 1965).

$135 \mathrm{Ch} .114, \S 4$, [1945] Tenn. Laws 356. 
ing authority. In pre-1949 discussions of urban renewal planning, nothing had been said about the potential role of outside consultants. For Capitol Hill, however, the authority turned to outside consultants and not, as they might have done, to the planning staff. The consultant's report ${ }^{136}$ suggested the redevelopment of the project area in relatively large parcels. An appreciation of their proposals can be gained from the map on page 70. The design was open and new buildings were to be massed in the southeast corner where they would complement new state offices. At this very point the report also proposed an "inviting doorway" ${ }^{137}$ composed of retail facilities, a theater and a parking garage. To the north and east, a shopping center was planned. Store and shop combinations were expected along the north rim, while wholesaling, light manufacturing and a motel were suggested on the west. A new parkway was proposed along the north side of the project area as part of an improvement in the city's circulation system. By the time Capitol Hill was completed in 1966, however, major changes had occurred which substantially diluted the objectives of the original redevelopment plan. Most of the expected redevelopment was not built, intended land uses were considerably altered and the redevelopment parcels originally outlined were gradually fragmented during the redevelopment process.

As the housing authority prepared for the redevelopment stage, it made several informal contacts, but no firm commitments with would-be developers. By the time project land was finally available, most of these potential redevelopers had disappeared. For example, the shopping center had been designed for a large national chain which lost interest. While this loss may reflect changing shopping patterns which make a central site less desirable, the housing authority attributed this and other difficulties to a strategic lawsuit which held up the sale of project land for four years after initial planning was completed. ${ }^{138}$ Whatever the reason, the loss of the shopping center unhinged the project. At the critical southeast parcel, the expected hotel-retail complex was not built, and the site is presently underutilized by a two-story motel. Light manufacturing and wholesale facilities planned on the west did not materialize, small office buildings have replaced the shopping center, and motels, apartment buildings and office buildings fill most of the remaining project area. Public facilities planned for the southeast corner (an auditorium and a parking garage) were built, as were two gasoline filling stations.

136 Nashville Housing Authority, Capitol Hill Redeveloparent Project (April, 1952) [hereinafter cited as PROJECT RePORT].

137 Id. at 35 . 1956).

138 See Starr v. Nashville Housing Authority, 145 F. Supp. 498 (M.D. Tenn. 
Shifts in project land use, particularly the introduction of highrise apartments in the project area, raised the possibility of unforeseen legal difficulties arising from the city's zoning ordinance and the plat restrictions that had been filed as part of the redevelopment plan. Zoning did not prove troublesome. While the applicable zoning was either industrial or commercial, the Nashville zoning ordinance was cumulative- "higher" residential uses were allowed in less restrictive zones. However, while the high-rise apartments technically are conforming under the zoning ordinance, they introduce a land-use mixture which dilutes one of the original project objectives.

Deed restrictions affecting land use, filed as part of the redevelopment plat, were potentially more troublesome. They limited project uses to "Commercial, light industrial and comparable uses," 130 specifically listing hotels, motels and office buildings, but not apartments. Indeed, the covenants specified "Hotels (but no other residential use)." ${ }^{140}$ Nevertheless, the housing authority legal staff interpreted the "comparable use" clause to permit the introduction of apartment buildings, and they were not challenged.

As redevelopment on Capitol Hill changed in character, the original redevelopment parcels became increasingly fragmented, since buyers could not be found who were willing to take the risk of developing larger tracts. Although it increased land disposition proceeds from an initial estimate of 3.9 million ${ }^{141}$ to 4.7 million dollars, parcelsplitting in Capital Hill also substantially affected project appearance and design, ${ }^{\mathbf{1 4 2}}$ increased site coverage and altered building relationships. Furthermore, to the extent that redevelopment on Capitol Hill was prompted by original deficiencies in plot layout, the splitting of tracts diluted an important redevelopment objective. Tract-splitting created no legal difficulties. Plat amendments were required under local ordinance, and were obtained in every case. ${ }^{143}$ While analogy to subdivision control suggests that the resubdivision of land within a project area should subject the redevelopment plan to additional

130 Nashuirle Covenants $\$$ VI(1).

$140 \mathrm{Id}$.

141 See Nashville Housing Authority, Capitol Hill Redevelopment Project: The END AND tHe BeginNing (1966).

142 Design objectives for the project were quite specifically articulated in the consultant's plans, but the plans did not propose a "strait jacket of restrictions" to carry out these proposals. PROJECr REPORT 46. The design controls contained in the restrictive covenants were rudimentary. Redevelopment plans had to show "Conformity and harmony of design and materials of construction with other improvements (existing or proposed) on the same or other building sites within the Project area." NAShVIILE Covenants $\$$ V (2) (a).

143 Telephone interview with John E. Acuff, Jr., Nashville Housing Authority, St. Louis, Mo.," May 5, 1967. Plan commission approval of the resubdivision of platted land was necessary. 
review, ${ }^{144}$ neither state law ${ }^{145}$ nor federal regulation ${ }^{148}$ treats the resubdivision of project parcels as a change in the redevelopment plan which requires a formal plan amendment.

Against this record, some detrimental development proposals for Capitol Hill, such as additional gasoline service stations, were resisted by the authority. Nevertheless, the housing authority lost much of the initiative during the redevelopment stage of the project, ${ }^{147}$ a loss not in the least restrained by the applicable legal controls. Much of the initiative for redevelopment shifted to private developers and, to this extent, the planning objectives for Capitol Hill were distorted by the pressures of the market.

\section{Slum Clearance in St. Louis: The Mill Creek Valley Project ${ }^{148}$}

\section{The Setting}

Experience with slum clearance in Nashville confirmed Bettman's expectations: in a city in which the housing authority was charged with the slum clearance function and absent a planning requirement in the state statute, initial redevelopment objectives would be distorted in the redevelopment process. St. Louis, working within an entirely different institutional structure, was nevertheless compelled to face some of the same problems.

A core city of 700,000 in an interstate metropolitan area of over two million, St. Louis is a declining and aging metropolis whose

144 Thus, the Connecticut subdivision control enabling act defines subdivision to be resubdivision, and then defines resubdivision to include "a change in a map of an approved or recorded subdivision [which] . . diminishes the size of any lot shown thereon." ConN. Gen. Stat. \$ 8-18 (Supp. 1966).

145 Indeed, the Tennessee law does not contain any provisions authorizing an amendment to an approved redevelopment plan. Ch. 114, § 4, [1945] Tenn. Laws 356.

146 Federal regulations require federal agency consent for any "material change" in the elements of the urban renewal plan. CuRRENT Manual \$10-3-3, at 1 (Feb. 15, 1965). However, land disposition parcels need not be shown as part of the urban renewal plan. Id. \$10-3-2, at 3-4 (March 29, 1965). The manual also provides that the subdivision plat of the project, if there is one, "shall show the bearings and dimensions of the boundaries of each disposal parcel or area to be offered separately." Id. \$14-2-3, at 5 (Aug. 18, 1965). Earlier regulations for plan amendments appear substantially similar. E.g., LPA MANUAL \$ 3-1-2, at 1 (Âpril 27, 1956).

147 Considerable pressure, the source of which is difficult to locate, was exerted to sell the land in the Capitol Hill project. Apparently the local authority was pushed by the Chamber of Commerce and other influential local interests to "show results" in the Capitol Hill area. The influence of Mayor Ben West is difficult to determine, but in some cases he was able to veto redevelopment proposals which he considered detrimental. One example was a federal office building which was proposed for the project area.

148 The discussion of slum clearance in the Mill Creek project that follows is based on Barbre, Slum Clearance in the Mill Creek Valley, 1967 (unpublished manuscript on file in Washington University Law Library). 
boundaries are permanently constricted by constitutional provision. ${ }^{140}$ Its housing stock is qualitatively better than Nashville's, ${ }^{150}$ and slum and urban renewal issues have been better documented through the years and appear to be more in the public domain. To some extent, this situation reflects the relatively open politics of a border city. For example, public referenda are required on bond issues, when needed to provide the local share of urban renewal costs. ${ }^{151}$ Compared with Nashville, the political and bureaucratic structure lacks continuity. City politics are partisan, the shift to Democratic control is relatively recent and mayors have changed frequently. ${ }^{152}$ Politics is not as personal as in Nashville, and the mayor is not as dominant a figure. Mayor Raymond Tucker, who spans the planning and redevelopment of the Mill Creek project in much the same way as Ben West spans the development of Capitol Hill, was not as aggressive an influence on urban renewal policy, although his role was considerable.

In assessing the political environment for slum clearance in St. Louis, Negro influence must again be considered. Mill Creek, like Capitol Hill, was a residential Negro slum, ${ }^{153}$ but, unlike Capitol Hill, it undoubtedly was the worst in the city. Although the proportion of Negroes in the total population is lower than in Nashville, ${ }^{154}$ Negro political leadership is more vocal. Nevertheless, while Negro opposition contributed to the defeat of an early bond issue for Mill Creek, the influence of Negro leadership on Mill Creek was definitely marginal.

Unlike Nashville, a formalized city planning function has been established in St. Louis since World War I. Continuity of leadership was provided by Harland Bartholomew, a nationally-known city planning expert who served as city planning engineer from 1916

149 A constitutional amendment, adopted in 1876, requires a favorable vote in both the City of St. Louis and the rest of St. Louis County in order to annex territory to the city. Mo. Const. art. VI, \$30.

150 Forty percent of St. Louis' rental housing is substandard. Disparities 218. However, the proportion of substandard rental housing in St. Louis is higher than in practically any major city on the eastern seaboard.

151 The Missouri constitution requires approval of two-thirds of the voters for a local bonded debt. Mo. Const. art. VI \$26.

152 Aloys P. Kaufmann, a Republican, was mayor from 1943 to 1949 , during the early planning period for Mill Creek. He was succeeded by Joseph M. Darst, a Democrat, who served from 1949 to 1953 and concentrated on public housing rather than slum clearance problems. Raymond $R$. Tucker, a Democrat, served as mayor from 1953 to 1965 . For an analysis of St. Louis voting behavior in local elections, see Exploring the Metropolitan Community 221-52 (Bollens ed. 1961).

153 A 1934 planning commission report indicated that the area already had been heavily Negro for some time. City PIAN Comanission, ANnUal Report 1933-34, at 34 .

154 According to the 1960 census, 29 percent of the population of St. Louis was nonwhite. DISPARITIEs 217. Negro immigration into St. Louis has been heavy. From 1940 to 1950 the increase was 41.4 percent; from 1950 to 1960 the increase was 40 percent. C. TAEUBER \& I. TAEUBER, supra note 119, at 117. 
to $1950,{ }^{155}$ but Bartholomew was replaced by Tucker at the start of his administration. No such continuity was provided in the urban renewal function. Although St. Louis had a public housing authority, a formally independent land clearance authority had to be established to carry out the urban renewal program, following the enactment of state legislation in 1951 requiring such an independent renewal agency. ${ }^{156}$ Tucker brought to St. Louis a new renewal director, who took responsibility for both public housing and the renewal effort.

In spite of its long planning history, St. Louis had not adopted a comprehensive city plan when planning for the Mill Creek project began in earnest after World War II. The city had seen a series of partial plan reports, most of them dealing with streets and similar physical facilities. Bartholomew had turned his attention to housing issues as early as $1917,{ }^{157}$ and in a 1936 report ${ }^{158}$ had focused on the loss of population from St. Louis and the need to take corrective steps to deal with bad housing conditions. The Mill Creek area, or parts of it, received attention in published reports dating back to at least $1927 .^{159}$

Although it was well-established by the time the Mill Creek project received serious consideration, the city planning function was weakly exercised, reflecting Bartholomew's style of indirect leadership and, perhaps, his part-time activity during the later years of his tenure. What most distinguishes the evolution of Mill Creek is the diffusion of initiative for planning decisions throughout the political and administrative structure, so that it is difficult to separate the project planning carried out for the Mill Creek area from the comprehensive planning that was conducted on the city level. Ad hoc decisions affecting the Mill Creek project continually altered initial city planning judgments, and were often made contemporaneously with Mill Creek plans. Shifts in redevelopment plans continued into the redevelopment stage.

Diffusion of initiative for urban renewal planning was not noticeably affected by the state urban renewal law, ${ }^{160}$ which contains

155 Some of the following information was given to the author by William Coibion, who was an assistant on Bartholomew's staff, and succeeded him as plan director, serving until 1957. Interview with William Coibion, in St. Louis, Mo., October 18, 1965 [hereinafter cited as Coibion Interview].

$15 B$ See note 160 infra.

157 City Plan Commission, Problems of St. Lours (1917). The report is discussed in N. Johnston, supra note 10 , at 123-28.

158 Ciry Plan CoMmission, URban LAND Policy (1936). The remedies proposed in the report are primitive, but do contain the seeds of the neighborhood rehabilitation concept. See N. Johnston, supra note 10, at 197-201.

159 See City Plan Commission, Annual Report 1933-34, at 34; City Plan Commission, Ten Year's Progress on the City Plan of St. Louis, 1916-1926, at 10 (1927).

160 [1951] Mo. Laws 300 (now Mo. ANn. Stat. $\$ \$ 99.300-660$ (1952)). 
extensive planning provisions carrying out the spirit, if not the exact structure, of the bill which Bettman had first proposed in 1943. The state statute dictated the dominance of city planning over the renewal planning process. Following the federal lead, a local governing body in Missouri may approve a redevelopment plan only if it conforms to the general plan for the community. ${ }^{161}$ Moreover, the slum clearance authority may recommend a redevelopment plan only after a general plan has been "prepared," ${ }^{162}$ and the planning commission must review the redevelopment plan for conformance with the general plan, before the redevelopment plan is submitted for local legislative approval. ${ }^{103}$ In addition, unlike most redevelopment laws, the Missouri statute requires the slum clearance authority to consider a wide variety of specified community objectives before recommending a redevelopment plan for adoption. These include such goals as the provision of adequate dwellings, the "healthful and convenient distribution of the population," the promotion of "sound design," provision for traffic and the coordination of community development. ${ }^{164}$ These broadly-stated objectives correspond to the list of general plan elements which are usually included in a comprehensive planning law, but how they are to be coordinated is not specified. Nor is the statutory intention clarified by language, derived from the Public Housing Conference draft of state legislation, which requires the redevelopment plan to "indicate" its relationship to community objectives. ${ }^{165}$ This language provides an ambiguous reference for a further provision, which follows the federal statute and requires that project land be sold at its "fair value" for uses in accordance with the redevelopment plan. $^{168}$ As in Tennessee, competitive bidding in the sale of project land is not required, and the definition of blighted areas is similarly handled by a listing of physically blighting conditions. ${ }^{167}$

\section{Selecting and Planning the Mill Creek Project}

Mill Creek, which is bisected by Market Street, an important east-west thoroughfare, was an extensive residential slum which in the final redevelopment plan covers 460 acres. Planning for the project can be divided into two stages. The first stage preceded the

161 Section 6(e), [1951] Mo. Laws 311.

162 Id. $\S 6(\mathrm{c})$, at 311 .

$183 I d . \S 6(\mathrm{j})$, at 313 .

$104 I d . \S 6(\mathrm{f})$, at 311 .

$165 \mathrm{Id}$. $\S 6(\mathrm{~d})$, at 311 .

$160 \mathrm{Id} . \S 7(\mathrm{a})$, at 313 .

167 Id. $\S \S 3(\mathrm{j}), 3(\mathrm{k})$, at 303 . 
enactment of the federal slum clearance program in 1949 and ended with the defeat of an urban renewal bond issue. The second stage followed the enactment of the state slum clearance legislation in 1951, which led to the successful initiation of the Mill Creek project. Both periods were marked by considerable mayoral initiative in the slum clearance effort and by adoption of city-wide plans, contemporaneous with urban renewal project planning.

Project planning in Mill Creek began as World War II drew to a close. It was spurred by a plan commission report which identified obsolete housing areas and recommended some of them for total clearance. ${ }^{168}$ This report isolated a collar of residential blight, including Mill Creek, which surrounded the central business core. While the report did not propose a strategy for eliminating this "slum collar," the existence of such a strategy has been affirmed by Bartholomew, and helps to explain both the early selection of Mill Creek for clearance and the construction of several public housing projects in the same general area. Slum clearance at this time was primarily concerned with the improvement of housing conditions. Missouri had passed an act in $1945^{169}$ which authorized redevelopment by private redevelopment companies and, in the absence of a federal subsidy, any plans for redevelopment were expected to be carried out by large eastern insurance companies.

Initiative for the first Mill Creek project came from Republican Mayor Aloys Kaufmann. Kaufmann took office in 1943, and in 1945 stepped outside the formal planning structure to appoint an Anti-Slum Commission ${ }^{170}$ to accelerate the city's slum clearance efforts. This step was taken with Bartholomew's approval, and reports issued from both the Anti-Slum and City Plan Commissions, ${ }^{171}$ pinpointing the Mill Creek area for clearance and, in very general terms, proposing redevelopment for public and private housing in what is now the northern half of the project. Meanwhile, in 1947, the plan commis-

168 City Plan Commission, St. Louis After World WAR II, at 17-18 (1942).

169 Section 1, [1945] Mo. Laws 1242 (now Mo. ANN. STAt. \$\$ 353.010-.180 (1966)). The law was allegedly drafted by a New York City insurance company interested in Mill Creek redevelopment. Interview with Aloys $P$. Kaufmann, in St. Louis, Mo., January 23, 1967 [hereinafter cited as Kaufmann Interview].

$170 \mathrm{Kaufmann}$ Interview. Mr. Kaufmann states that Bartholomew concurred in the appointment of the Anti-Slum Commission. Coibion has provided the more reasonable explanation: the Anti-Slum Commission was appointed so that the pressures generated by slum clearance recommendations would be taken off the city's planners. Coibion Interview. See also St. Louis Post-Dispatch, July 9, 1945, at $1 \mathrm{~A}$, col. 1.

171 St. Louis City Plan Commission, Thirteenth Annual Report 10 (1946); St. Lours Anti-Slum Commission, Report to the Community (1947). This article does not analyze the St. Louis University expansion proposal for the northwest corner, which was included in project plans from this date. Coibion Interview. 
sion, also spurred by Kaufmann, prepared for the first time a general plan for the city. ${ }^{172}$ While this plan mapped obsolete housing areas and discussed slum clearance in general terms, it contained no specific redevelopment proposals, even though preliminary plans were proposed for Mill Creek at the same time. In the northern section of what is now the Mill Creek project, the plan indicated high density residential uses, while industrial uses were shown in what is now the southern section. ${ }^{173}$ This general land use scheme ultimately became the framework for Mill Creek planning, although the 1947 city plan differed somewhat from the land-use scheme that appeared in the project.

These early proposals for Mill Creek were delayed by the defeat of an urban renewal bond issue in $1948,{ }^{174}$ but revived when Mayor Tucker took office in 1953. By this time, important changes had occurred in the local climate for the urban renewal effort. Federal and state slum clearance laws had been passed, and a city land clearance authority created. Public housing projects had been built and others were contemplated elsewhere in the slum collar, ${ }^{175}$ and this effort was given as a reason for dropping public housing from Mill Creek plans. ${ }^{176}$ Tucker and his renewal director still saw Mill Creek as an opportunity for an impressive slum clearance program in St. Louis. Largely on their initiative, in 1954, the Mill Creek project was designated for redevelopment ${ }^{177}$ and an urban renewal bond issue was approved the following year.

The Mill Creek project, at this stage, was substantially changed in size and character, ${ }^{178}$ as the project was extended southward to (1947)

172 City Plan Commission, Comprehensive City Plan: St. Louis, Mo.

${ }_{173} I d$., plate nine. A mixture of industrial and commercial uses also was shown for what is now the northeast corner of the Mill Creek project.

174 St. Louis Post-Dispatch, Nov. 3, 1948, at 6A, col. 4.

175 See Washington University Urban Renewal Design Center, Checklist

of Slum Clearance, Public Housing, Urban Renewal, Remabilitition and Conservation Projects in the St. Louis Metropolitan Statistical Area 5-6 (Nov. 7, 1966).

176 St. Louis Post-Dispatch, Aug. 8, 1954, at 1A, col. 8.

177 Most St. Louis informants are of the impression that the initiative came from Tucker and the director of the land clearance authority.

178 Legitimate questions can be raised about the size of the project, which is large as renewal projects go. Consideration was given to proceeding in stages, but allegedly this approach was overcome by a political desire to make an impressive start on slum clearance. Coibion Interview. The project also formed a natural planning area. Also open to question is the omission of a large rectangular tract on the area's southern edge. This tract contains the switching yards of the St. Louis Terminal Railroad. The yards were not available for redevelopment at the time the project was created, but have since fallen into disuse and could now be included. Interview with Clarence Turley \& Robert Saunders, St. Louis Redevelopment Corp., in St. Louis, Mo., Jan. 6, 1967. A more flexible approach might have been to include the tract in the project, but designate it, to use the administrative term, as "Not To Be Acquired." A later plan amendment could then have brought the area into active redevelopment plans. 
include large areas earmarked for industrial development. This change reflects both increasing concern with problems of the economic growth of St. Louis, and a decision to use the opportunities presented for the first time by the federal law for industrial redevelopment of residential slums. Both these concerns are reflected in a preliminary Plan Commission report published in 1953. ${ }^{179}$ This report, which did not cover all of what was to become the Mill Creek project, contained preliminary plans both for industrial redevelopment, generally south of Market Street, and for commercial redevelopment in the center. Housing was deemphasized. When the final project plan ${ }^{\mathbf{1 8 0}}$ appeared, the area designated for non-residential uses was reduced. As the map on page 72 indicates, industrial redevelopment was proposed for the southern sections. While marginal commercial areas remained, redevelopment for housing was contemplated for almost all of the remaining area. The project plan somewhat modified the 1947 general plan and proposed intermediate residential densities, ${ }^{181}$ which were also reflected in the redeveloper's proposals for mixed high-rise and low-rise residential development. This basic concept also appears in a new land-use plan for the city which was published in 1956, ${ }^{182}$ contemporaneous with project planning for Mill Creek. ${ }^{183}$ The city plan does not concentrate explicitly on urban renewal and, in an important departure from the 1947 plan, does not distinguish residential areas on the basis of density. ${ }^{184}$

Discussions of the impact of the city plan on urban renewal had emphasized the importance of the city planning process in coordinating urban renewal with other public projects throughout the city. Two major highways located in the Mill Creek area were expected to encourage industrial redevelopment, and their scheduled completion, along with the execution of the urban renewal program, was of critical

179 St. Louis City Pian Commission, Rebullding Industry-Comarerce in St. Lours (1953). This report centered on the use of redevelopment powers to make more industrial land available in St. Louis. Early planning for Mill Creek had included a circular railroad spur to serve the intended industrial redevelopment. Plans for the spur were dropped because of the expense of bridging the expressway. Turley \& Saunders Interview, supra note 178.

180 Land Clearance for Redeveloparent Authority of the City of St. Louts, Redevelopment Plan for Mill Creek Valley Project (Feb. 19, 1958) [hereinafter cited as MILL CREEK PLAN].

181 The plan adopted a residential density of 20 to 40 dwelling units per acre, which is considered to be in the intermediate range. MILL CREEK PIAN 7.

182 St. Louis City Plan Commission, Land Use Plan (1956).

183 The preliminary project report for Mill Creek was completed in the same year. St. Louis Land Clearance Authority, Preliminary Project Report-Mill Creek Valley Redevelopment Project (1956).

184 LAND USE PLAN, supra note 182, facing p. 30 . Urban renewal is mentioned, $i d$. at 29 , but possible slum clearance areas are not discussed in detail. Commercial areas at the edge of what was to become the Mill Creek project are pinpointed for the first time. 
importance. One highway, the north-south distributor, has not been built as of this writing, while the completion of the east-west expressway was substantially delayed. Delays in completing the expressways adversely affected the progress of the renewal project, and resulted in the loss of at least one potential redeveloper.

Yet, these unfortunate difficulties cannot really be cited as proof of the failure of city planning. Lack of financing was the critical factor which delayed the completion of the north-south distributor; it was a factor in the delay of the other highway as well. Urban expressways are expensive to build, and are now usually found as part of the National System of Interstate and Defense Highways, which enjoys 90 percent federal financing; neither of the Mill Creek expressways is included in the Interstate system. Timing may have been a contributing cause. The Interstate highway system was first authorized by the Federal-Aid Highway Act of $1956,{ }^{185}$ by which time the earlier planning by St. Louis had fixed expressway locations in Mill Creek which did not fit in with Interstate priorities. Institutional changes in an important federal-aid program clearly affected the city's ability to implement local planning objectives as they had been formulated in highway proposals.

The process by which these highways came to be located in the Mill Creek project area illustrates the way in which external pressures may seriously interfere with the coordination function of planning. Although both highways had originally been located on the basis of city planning studies, their presence in the Mill Creek project was only in part the result of an explicit planning judgment. The eastwest expressway was shown in what was to become the project area as early as the 1947 city plan. ${ }^{186}$ In the preliminary project plan, published in 1953, it had been shown along the southern project edge. ${ }^{187}$ By the time the Mill Creek project was designated in 1954, however, this highway had been officially approved on a line that ran through the middle of the project, turning south-east at a point near its center. ${ }^{188}$ Moving the highway to this location definitely altered its

18570 Stat. 374 (1956).

186 Comprenensive City PlaN, supra note 172, plate nineteen.

187 REBUII DING INDUSTRY-COMMERCE IN ST. Lours, supra note 179. See plate showing Mill Creek Valley Plan, page 73 infra.

188 A 1950 study discussed three alternatives for the expressway route and favored a location which would have put the expressway at the southern boundary of the Mill Creek Project. St. Lours URban ArEa Expressway Project, St. Louts Urban Area Expressways, InterIM Report, St. LouIs, Mo. 18-22 (1950). Coibion and his staff favored this route because they felt it would supplement the local street system, while a route through the center of the project would be superimposed on the local system and would require the reconstruction of a prewar expressway. Coibion Interview. The plan commission rejected the southern route in 
impact. The final location was imposed on the city by severe pressure from the state highway department, and was not favored by the city's planners. The second major highway, running north to south, was also shown on the 1947 city plan, but at that time was outside the Mill Creek area. ${ }^{189}$ This highway was later shifted just inside the project, to its eastern edge. While the planners concurred in this judgment, the major reason for the shift was to increase the amount of local non-cash contributions to the Mill Creek project. ${ }^{190}$

\section{Redevelopment in Mill Creek ${ }^{191}$}

Redevelopment experience in Mill Creek is not as complete as in Capitol Hill and, in early 1967, substantial areas remain undeveloped, although most of the project land has been sold. In spite of its more formal city planning background, however, Mill Creek experienced the same shift in redevelopment uses, accompanied by a splitting of the original redevelopment parcels, although not on the same scale as in Capitol Hill. ${ }^{192}$

In the residential area, changes during redevelopment primarily have affected the intensity of residential use, as initial plans for high

response to pressure from the state highway department. ST. Lours CITY PLAN CoMMIssIon, THIRTY-NINTH ANNUAL REPORT 15 (1955). Coibion indicates that pressure to conform to the route selected by the state highway department also came from Mayor Tucker. Coibion Interview.

189 Comprenenstve City Plan, supra note 172, at plate nineteen.

190 Coibion Interview. Coibion had opposed the earlier route because of its adverse effect on property values.

191 Selection of a redeveloper for Mill Creek created a controversy which ended in the designation of two redevelopers, one of them local, for most of the project area. This choice followed the rejection of a well-known out-of-town urban redeveloper. The land disposition technique used in Mill Creek differed from that used in Capitol Hill, and is not typical of urban renewal projects generally. The residential section was sold to a redeveloper who carried out and kept title to the new development. In the industrial area a redevelopment company developed individual tracts for resale separately.

$182 \mathrm{It}$ is more difficult to evaluate the extent of parcel-splitting in Mill Creek than in Capitol Hill. The original tracts in Mill Creek have been substantially cut up in the disposition process. This conclusion is accurate, however, only to the extent that it refers to the disposition tracts as they are shown on the recorded Mill Creek Valley plat. No changes have been made on the recorded plat, as conveyances of parts of each recorded tract have been made from the plat by means of metes and bounds descriptions. Turley \& Saunders Interview, supra note 178. The tracts divided for redevelopment in the industrial area conform in general outline to an illustrative site plan prepared by the Mill Creek redevelopers at the time the contract for redevelopment was awarded. St. Louis Redevelopment Corp. \& City \& Suburban Homes $\mathrm{Co}$, Mill Creek Valley Redevelopment Project (undated). Thus, it was intended from the beginning to divide the industrial tracts shown on the Mill Creek Valley plat. However, it should be stressed that the illustrative site plan is not a formal part of the Mill Creek Valley redevelopment plan. Furthermore, even accepting as official the size, outline and character of the redevelopment sites shown on the illustrative plan, there has been some departure from the intended redevelopment and some fragmentation of redevelopment parcels, especially in the center of the project area. 
density development have been modified to permit the introduction of a town house project which blankets much of the residential area. This development, in turn, was made possible by an attractive federal mortgage insurance program for middle-income housing, which did not become statutorily available until three years after the redevelopment plan had been adopted. ${ }^{193}$ Plans for the industrial area have also been altered in the redevelopment stage. One parcel on the western edge of the project has been shifted to residential use to permit the construction of an apartment for the elderly, taking advantage of a direct federal loan program which again was not available when the redevelopment plan was approved. ${ }^{194}$ Elsewhere, an expansion of the expressway right-of-way diminished the area available for industrial purposes. ${ }^{195}$

Strip commercial development has replaced intended industrial use of the redevelopment tracts which front on Market Street, reflecting the expectations of earlier plans which had indicated commercial development in this area. This change, especially at a key point in the center of the project, was accompanied by a splitting of the original redevelopment tracts. As in Nashville, neither the change in use nor the division of the original parcels was inhibited by the restrictions contained in the project plan. While resubdivision of redevelopment tracts needs the approval of the slum clearance authority, ${ }^{196}$ this requirement did not impose a serious obstacle. ${ }^{197}$ The land-use restrictions which are part of the project plan simply repeat the "J" industrial zone designation which the zoning ordinance applies to the industrial area. ${ }^{198}$ This zone is meaningless. Anything is permitted except for certain listed industrial uses which are offensive in character. Under the circumstances, the statutory injunction that project land be sold for "uses" shown by the redevelopment plan has little meaning.

As in Nashville, rehousing objectives were disappointed by the relocation experience. A relocation problem was recognized from

19312 U.S.C. $\$ 12151$ (d) (3) (Supp. I, 1966). This program is known as the "Section 221(d) (3) program." In part, it authorizes long-term loans at below market interest rates to promote the construction of rental units to be offered at moderate rentals to qualifying middle-income families. The program does not provide low-cost housing. For discussion, see Stein, The Section 221(d)(3) Beloze Market Interest Rate Program for Low and Moderate Income Families, 11 N.Y.L.F. 16 (1965).

19412 U.S.C. \& 1701 (q) (1964).

195 Compare MIIL CREEK PLAN, exhibit 1, at 9 (Feb. 19, 1958), with MnL Creer Plan, exhibit 1, at 9 (rev. March 4, 1965).

198 Mirl CREek Plan 7.

197 Turley \& Saunders Interview, supra note 178.

198 MIrL CREER PLAN 7. For the regulations governing "J" Industrial Districts, see Rev. CodE of ST. LouIS \$\$ 913.010-.050 (1960). 
the early planning stage of Mill Creek. ${ }^{199}$ Area residents could not afford the housing to be built in the project, so that low-rent and low-income housing would have to be found elsewhere. The authority expected public housing to meet most of these needs since 89 percent of the site residents were presumably eligible. ${ }^{200}$ Again, public housing was accepted by only a few families, $164^{201}$ out of a population estimated as high as $21,000 .^{202}$ From its own records, the authority relocated only 8,213 people; about 15 percent are known to have gone into substandard housing. ${ }^{203}$

\section{Problems in URban Renewal}

Generalizations from two case studies are always difficult, especially about a program as varied as urban renewal. Both Mill Creek and Capitol Hill are early projects, substantial in size, which replaced badly blighted Negro slums in the city core with nonresidential uses and residential redevelopment serving an entirely different social class. Other types of projects present different types of problems. Nevertheless, within these limitations, some conclusions may be drawn concerning the influence of comprehensive city planning on urban renewal programs.

In both Nashville and St. Louis, problems developed in the implementation of the urban renewal projects which distorted initial planning judgments. For the most part, these are difficulties not foreseen in the discussions leading up to the imposition of the planning requirement in urban renewal legislation, and they seriously frustrate the role of comprehensive planning in the urban renewal process. Some of these difficulties are external to the city planning function; some are internal.

The Mill Creek and Capitol Hill projects are both characterized by a loss of public initiative in the redevelopment stage, resulting in a change, if not a distortion, of initial redevelopment objectives by pressures of the market. While the sale of project land was supposed to be governed by the redevelopment plan, the legal sanctions available to enforce the plan were not strong enough to hold up under pressure, and in Nashville were openly disregarded by the urban

199 Bond Issue Screentng Committee, Report of the Subcomarittee on Slum Clearance, exhibit 2 (1955).

200 St. Louis Post-Dispatch, Feb. 28, 1960, at 3A, col. 3.

201 Id.

202 Bond Issue Screening Committee, Report of the Subcommitree on Slum Clearance, exhibit 3 (1955).

203 St. Louis Post-Dispatch, May 28, 1961, at 1A, col. 1. 
renewal authority. When redevelopment is left to private entrepreneurs, the implementation of planning goals is dependent upon the response of the private market. Without additional public intervention to secure a better market reaction, it may be that the market will not function well enough in the urban core to carry out planned urban renewal objectives. Institutional changes of this kind have already been attempted. One important new program, which provides attractive, federally-insured financing for middle-income housing, led to the introduction of the town house development in Mill Creek.

The institutional framework for federal urban renewal assistance and other developmental programs contributed even more directly to the character of redevelopment in these projects. Thus, motels were introduced in Capitol Hill prior to the inclusion in the federal statute of a provision precluding motels in urban renewal projects, unless a finding is made that there is a need for such facilities. ${ }^{204}$ Early planning of expressways in St. Louis, in advance of the shift to the almost total federal financing of the Interstate system, contributed to difficulties in project execution, because the planning process was not able to respond to the new federal program. Later urban renewal projects in Nashville, by way of contrast, reacted quickly to the opportunities presented by the Interstate system, because city planning in that city was not as formalized and rigid. ${ }^{205}$ The opportunities for industrial redevelopment, presented for the first time by the enactment of the federal urban renewal law in 1949, clearly influenced the character of the Mill Creek project. Without the subsidy available from the federal government to support the local urban renewal effort, an industrial redevelopment program in St. Louis would have been impossible, and the planning issues associated with such a program would never have received public consideration.

Problems also flow from the failure to clarify the uneasy boundaries between the domain of the planner and the decision-making arena which is reserved to the political process. Since local legislative approval is required at several stages in an urban renewal project, political influence has an institutionalized role apart from the informal opportunities which are available to affect program direction. Other case studies have described communities in which the urban renewal director has become an administrative entrepreneur, with considerable

204 U.S. Housing Act of 1964, 42 U.S.C. $\$ 1456$ (g) (1964).

205 Nashville's next urban renewal effort, after Capitol Hill, was construction of the urban leg of an interstate highway. It was used to eliminate substandard housing and to form an internal dividing line between the industrial and residential sections of the project area. 
de facto power over the political structure. ${ }^{206}$ Power over decisions affecting urban renewal in St. Louis and Nashville was more evenly shared between the planners and urban renewal administrators on the one hand, and political officeholders on the other. Nevertheless, mayoral influence in both cities was quite apparent and occasionally critical. Mayoral initiative was largely responsible for Mill Creek, while a mayoral veto could have blocked the Capitol Hill project.

What role the political structure should play in the public decisionmaking process affecting planning raises other more difficult issues. The political officeholder is faced with technical judgments backed by professional expertise, and the difficulty of constructing a policy alternative without the assistance of competent professional staff answerable only to him. Often, his only choice is to approve or veto. $^{207}$ In a society which values separation of governmental powers, these problems will continue to be troublesome, especially in programs like urban renewal where legally independent bodies in the form of local authorities have been selected to implement program objectives.

Other problems arise from limitations inherent in the city planning concept itself. To some extent, these difficulties derive from disparities in scale. Generalized and simplified physical plans for the city are hard to apply in the urban renewal program, in which precise developmental decisions must be made at the project level. Land-use plans in St. Louis, for example, were much too crude to guide the developmental patterns that finally took shape in Mill Creek. To avoid these problems, Bettman had insisted in his model act that detailed project planning precede even the selection of urban

206 See, e.g., H. Kaplan, Urban Renewat Polittcs: Sium Clearance in NEWARK (1963).

207 In Nashville, Mayor West's approval of the Capitol Hill project did not in any way affect the plans that were drawn up for its redevelopment. Mayor Tucker also participated in redevelopment decisions, and met regularly with the Mill Creek redevelopers. Interview with Raymond $\mathrm{R}$. Tucker, in St. Louis, Mo., December 22, 1966. Like West, however, his influence was marginal, although he was clearly instrumental in blocking some undesirable redevelopment proposals. Again, as in Nashville, would-be filling station developers had to be resisted in the Mill Creek area. See note 143, supra.

Clavel has noted the difficulties which the politician faces:

The Binghamton [New York] decision for extensive redevelopment . . . was made by a small group of professional planners who . . . had a command of relevant data, technique and legal limitations, not available to other groups. . . This meant that, whatever political sanctions might be placed on the planning decision later could not be backed up authoritatively with technical knowledge. Political pressures might reject the planner's decision, but they could not, by themselves, formulate an alternative.

P. Clavel, A Planning Decision for Extensive Redevelopment in Binghamton 5 (undated) (unpublished manuscript on file in Washington University Law Library). This is precisely the dilemma which. Ben West faced when he had to make a decision on the Capitol Hill project. In Louisville and Memphis, the writer found that political leaders had rejected early urban renewal projects, leading to considerable delays in the redevelopment programs in those cities. 
renewal projects. But the problem is not only one of detail, for even detailed physical planning leaves untouched important issues such as the social and racial composition of the project and the setting of priorities in slum clearance. Time is another independent factor which is not reflected in city or even project planning. When more than one redeveloper is involved, and a project is developed piece-meal, land-use, density and site relationships change as the project moves through the redevelopment stage. What is built first affects what is built later. ${ }^{208}$

Neither is the historic planning goal of coordination easy to achieve in the urban renewal context. Important public programs affecting the urban environment are separately authorized, with the result that chains of administrative responsibility are vertical and independent. For example, highway administration is lodged in a state agency with statewide responsibilities, and is responsible to an independent federal agency, professionally unconcerned with urban renewal. Cooperation between highway and renewal agencies is expected, ${ }^{209}$ but it is not institutionalized. As Mill Creek illustrates, unless a city is able to exert strong influence on the state highway program, redevelopment plans are liable to be frustrated by the state highway department.

Even more critical problems arise from lack of agreement on the substantive role of planning in urban renewal. This problem is aggravated by a conflict over housing and non-housing objectives. Issues such as the impact of slum clearance on the racial distribution of the housing supply, so important in the Nashville and St. Louis projects, were simply not considered. Public policies on problems such as racial integration, the provision of low-cost housing and the relationship of low-income neighborhoods to the transportation system and centers of employment are more important than maps which are restricted to physical uses of land. Indeed, a strong case can be made for presumptively accepting the physical development objectives in urban renewal projects, so long as there is effective planning for related social and racial problems. Federal financing for local Community Renewal Programs ${ }^{210}$ now makes it possible to deal with

208 Use of the urban renewal plan amendment process as a method of handling these changes has been little considered. See Current Manual §10-3-3 (Feb. 15, 1965). The plan must be amended whenever there is a "material change" in any of the plan elements. Criteria against which plan amendments are to be considered are not given.

200 CuRrent Manual $\$ 10-1$, at 2 (June 29, 1965).

21042 U.S.C. $\$ 1453$ (d) (1964). The Community Renewal Program (CRP) must conform to "the general plan of the locality as a whole." Id. It is considered to be a form of "middle-range" planning which seeks to implement in the shorter view the longer-range goals of the comprehensive plan, Gaby, The Evolution of an 
some of these questions on a more sophisticated level than was possible in earlier city planning. While it is still too early to evaluate the Community Renewal Program, ${ }^{211}$ its impact will necessarily be limited, unless it faces some of these hard issues.

Since constitutional requirements are satisfied by a program based on the elimination of substandard conditions, a comprehensive planning requirement in urban renewal is not a constitutional necessity. If, however, one of the functions of city planning in urban renewal is to provide an external review of redevelopment objectives in a program which enjoys not only the compulsory powers of eminent domain, but also a substantial public subsidy, then the planning function must be made legally meaningful. So far, we have been notably unsuccessful in translating the community planning requirement into a legal framework in which planning judgments would carry effective sanctions. Courts provide the only external legal check on the redevelopment process, and courts will not review the important questions of project selection, project size and project priorities. ${ }^{212}$ Judicial refusal to intervene may well reflect an awareness of the political sensitivity of these issues. Although a wide range of decisions in urban renewal programs could be made judicially reviewable under specified planning criteria, we may choose to leave their resolution to the political and administrative process.

Should we decide to provide effective sanctions for comprehensive planning judgments, the redevelopment stage will become a more critical checkpoint than project qualification, which is presently based on substandard physical conditions. Provided the redevelopment plan contained a meaningful limitation on redevelopment, each redevel-

Idea in the CRP: A Critical Evaluation, in Am. SOC'Y of Planning Officiars, PLANNING 1966, at 20 . A CRP directive states the elements of the programming process, but does not in any way attempt to articulate the substantive content of possible urban renewal strategies. See U.S. Housing and Home Finance Agency, Urban Renewal Administration, LPA Letter No. 276, at 9-10 (Aug. 19, 1963). Nashville's planners view the CRP as unnecessary. A St. Louis CRP study was getting under way as of this writing.

211 Many of those associated with urban renewal envision the Community Renewal Program as providing a more viable planning tool which will remedy acknowledged deficiencies in city planning. Interviews with CRP directors and staff in several large cities suggest, however, that while the CRP can be of help in revealing the consequences of urban renewal planning and identifying blighted and slum areas, the CRP leaves untouched the problem of marketing project land, which must be solved in a regional frame of reference which the urban renewal program and the CRP do not compel.

212 In zoning cases, some courts have uncritically accepted the policy content of the master plan. See, e.g., Cleaver v. Board of Adjustment, 414 Pa. 367, 200 A.2d 408 (1964); cf. Christine Bldg. Co. v. Troy, 367 Mich. 508, 116 N.W.2d 816 (1962); Ott v. West New York, 92 N.J. Super. 184, 222 A.2d 541 (1966) (upheld the renewal authority's decision to accept the low bid for project land in order to facilitate the building of middle-income housing). 
opment proposal could be reviewed judicially for conformance to the redevelopment plan's intentions.

Judicial review on this basis would be ineffective, however, when the substantive content of the redevelopment plan does not provide a meaningful framework for redevelopment. Mill Creek provides a case in point. Courts could remedy these deficiencies only by reviewing the policy content of urban renewal plans, an involvement in policymaking which would be unwise.

Yet alternatives to judicial review are not easy to construct. Substantive administrative policies for urban renewal planning could be delineated at the federal level, and local renewal objectives reviewed by the federal agency. But federal agency review may not be meaningful for a variety of reasons, including the political repercussions of cancelling or modifying locally-determined policies. The effectiveness of such review also is open to question. In neither Mill Creek nor Capitol Hill did the federal agency seriously affect the redevelopment program. Perhaps external review is neither possible nor desirable.

So long as urban renewal concentrates on the elimination of clearly substandard areas, no constitutional problems are raised by the power to condemn for public use. Community Renewal and related programs, however, are shifting public attention from the elimination of substandard conditions within geographically circumscribed projects to a more comprehensive approach to the redevelopment of the city. Should this change in direction continue, the need to exercise compulsory acquisition powers outside conventional slum areas may raise difficult constitutional problems. The role of city planning, in justifying the rationality and legality of the "slum clearance" effort, would then require serious re-examination. 


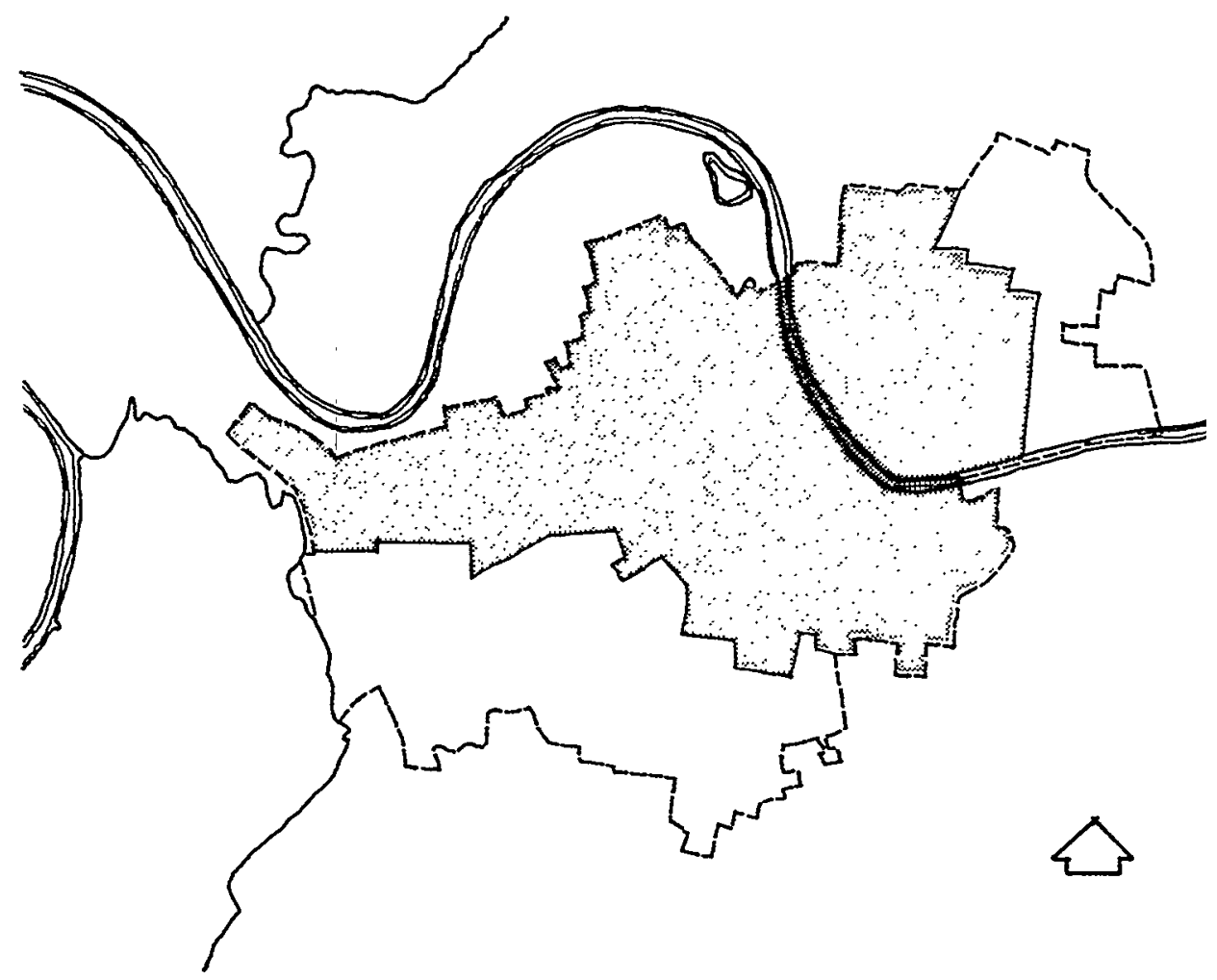

NASHVILLE, TENNESSEE : Substandard housing 1949 Note: Shaded area-Census tracts with $50 \%$ or more substandard 


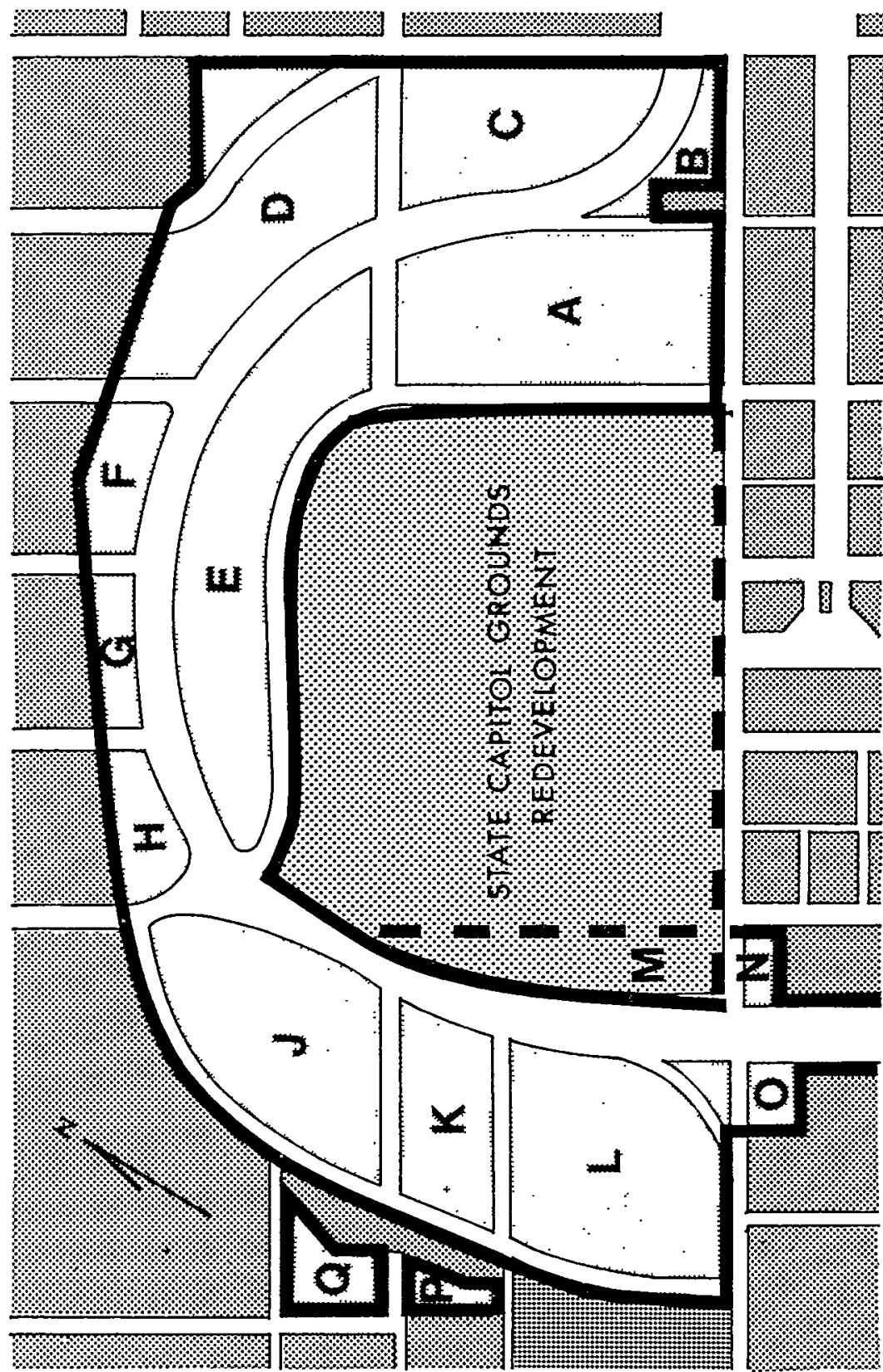

$\frac{2}{2}$

$z$
$\frac{1}{n}$
$\frac{1}{n}$
0
$\frac{a}{0}$
$\frac{1}{0}$

・.

$\vdash$

u

O

$\frac{\alpha}{a}$

$\sum_{0}^{\frac{5}{z}}$

I

$\frac{1}{\frac{1}{2}}$ 

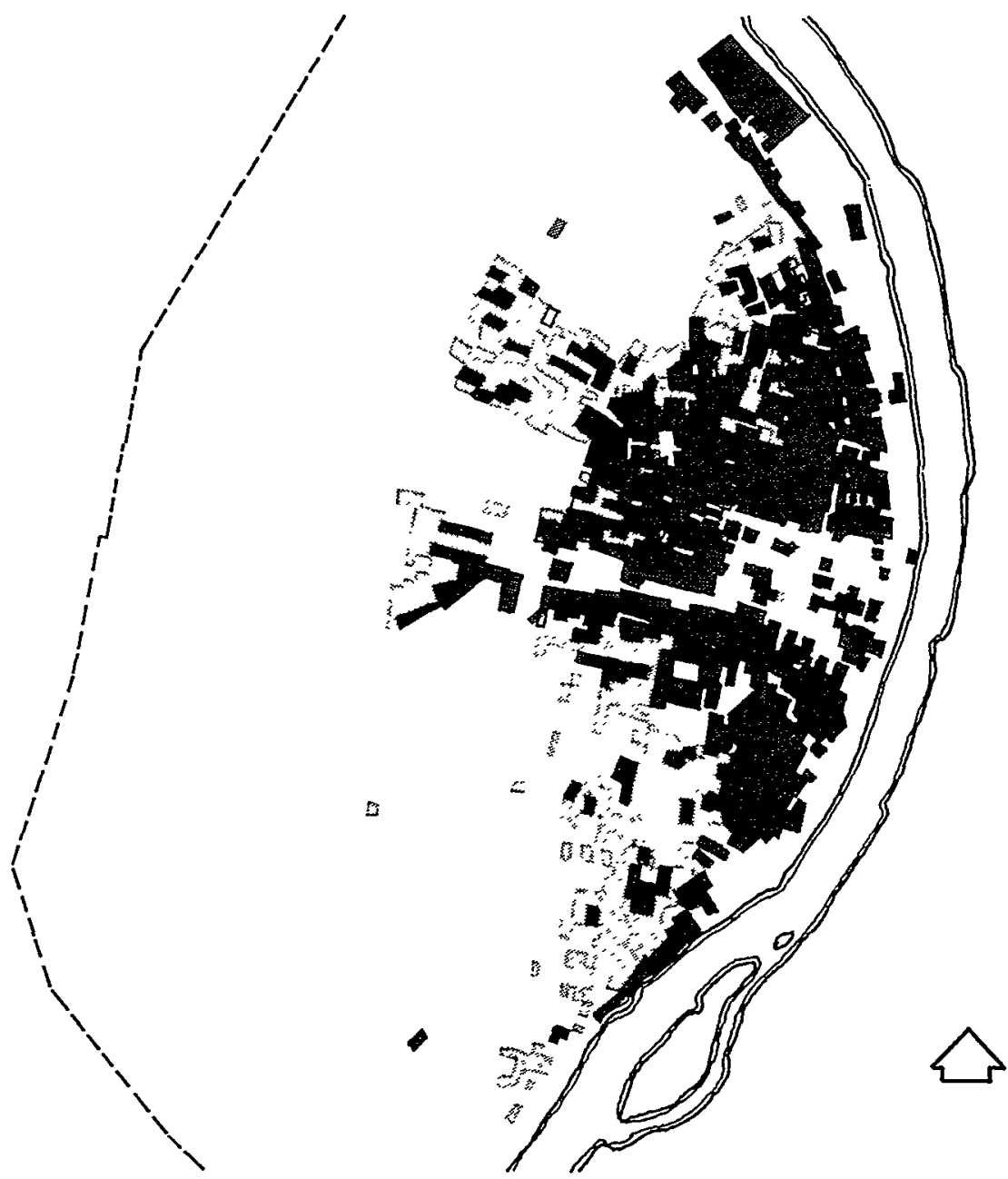

ST.LOUIS, MISSOURI: Substandard housing 1942

Clearance - $60 \%-100 \%$ substandard

$\therefore$ Rehabilitation - 20\%-59\% substandard 


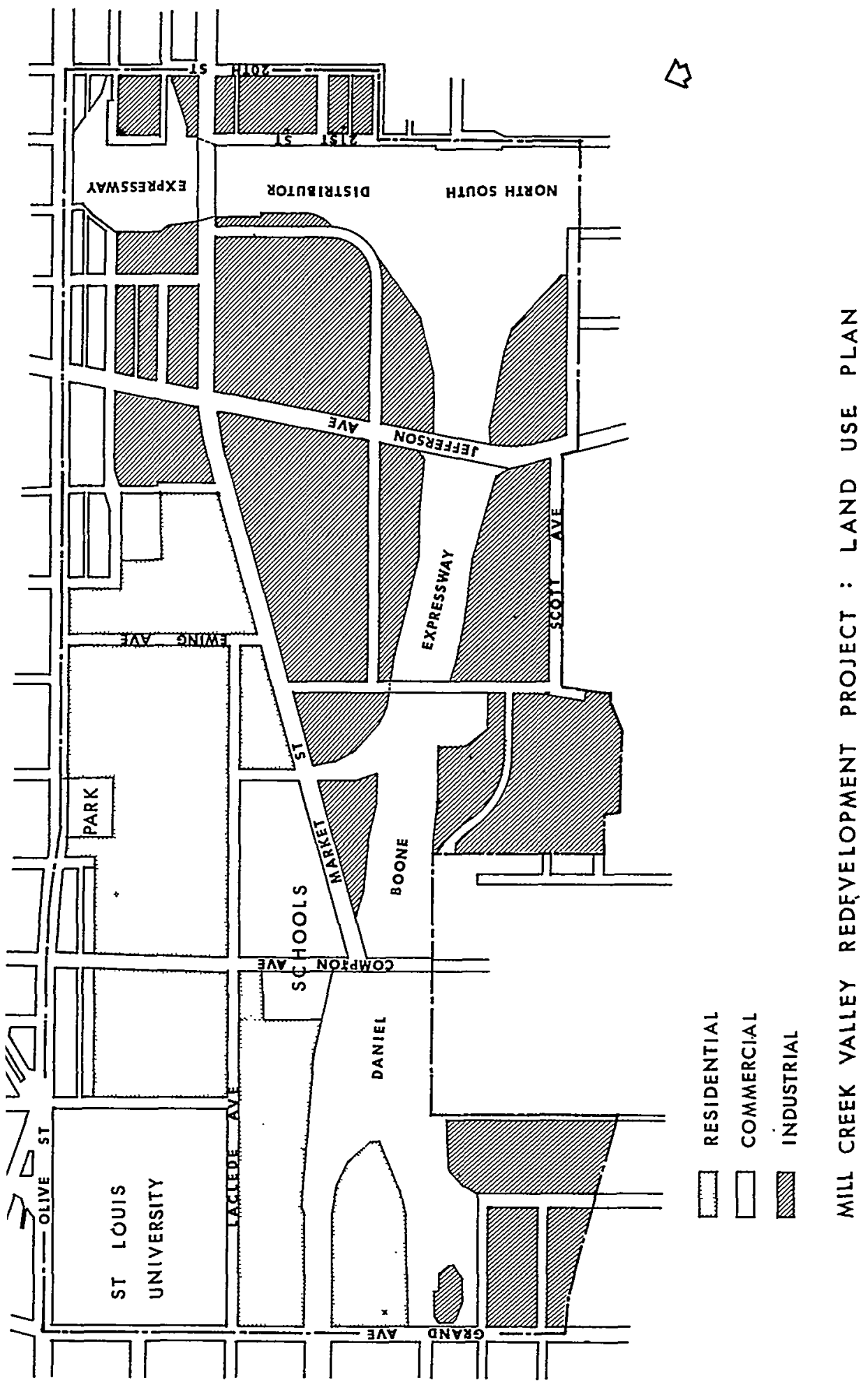

